\title{
Origin and Sources of Minerals and Their Impact on the Hydrocarbon Reservoir Quality of the PaleogeneLulehe Formation in the Eboliang Area, Northern Qaidam Basin, China
}

\author{
Bo Chen ${ }^{1,2, *}$, Feng Wang ${ }^{1, *}$, Jian Shi ${ }^{2}$, Fenjun Chen ${ }^{3}$ and Haixin Shi ${ }^{1, *}$ \\ 1 Guangxi Colleges and Universities Key Laboratory of Beibu Gulf Oil and Natural Gas Resource Effective \\ Utilization, Beibu Gulf University, Qinzhou 515000, China \\ 2 Key Laboratory of Petroleum Resources, Gansu Province/Key Laboratory of Petroleum Resources Research, \\ Institute of Geology and Geophysics, Chinese Academy of Sciences, Lanzhou 730000, China \\ 3 Exploration \& Production Research Institute of Qinghai Oilfield Company, petroChina, Dunhuang 736202, \\ China \\ * Correspondence: cbo-11@163.com (B.C.); fefe12138@163.com (F.W.); shihaixin2006@163.com (H.S.)
}

Received: 13 May 2019; Accepted: 12 July 2019; Published: 15 July 2019

\begin{abstract}
The Lulehe sandstone in the Eboliang area is a major target for hydrocarbon exploration in the northern Qaidam Basin. Based on an integrated analysis including thin section analysis, scanning electron microscopy, X-ray diffraction, cathodoluminescence investigation, backscattered electron images, carbon and oxygen stable isotope analysis and fluid inclusion analysis, the diagenetic processes mainly include compaction, cementation by carbonate and quartz, formation of authigenic clay minerals (i.e., chlorite, kaolinite, illite-smectite and illite) and dissolution of unstable materials. Compaction is the main factor for the deterioration of reservoir quality; in addition, calcite cement and clay minerals are present, including kaolinite, pore-filling chlorite, illite-smectite and illite, which also account for reservoir quality reduction. Integration of petrographic studies and isotope geochemistry reveals the carbonate cements might have originated from mixed sources of bioclastand organic-derived $\mathrm{CO}_{2}$ during burial. The quartz cement probably formed by feldspar dissolution, illitization of smectite and kaolinite, as well as pressure solution of quartz grains. Smectite, commonly derived from alteration of volcanic rock fragments, may have been the primary clay mineral precursor of chlorite. In addition, authigenic kaolinite is closely associated with feldspar dissolution, suggesting that alteration of detrital feldspar grains was the most probable source for authigenic kaolinite. With the increase in temperature and consumption of organic acids, the ratio of $\mathrm{K}^{+} / \mathrm{H}^{+}$increases and the stability field of kaolinite is greatly reduced, thereby transforming kaolinite into mixed layer illite/smectite and illite. Within the study area, porosity increases with chlorite content up to approximately $3 \%$ volume and then decreases slightly, indicating that chlorite coatings are beneficial at an optimum volume of 3\%. A benefit of the dissolution of unstable minerals and feldspar grains is the occurrence of secondary porosity, which may enhance porosity to some extent. However, the solutes cannot be transported over a large scale in the deep burial environment, and simultaneous precipitation of byproducts of feldspar dissolution such as authigenic kaolinite and quartz cement will occur in situ or in adjacent pores, resulting in heterogeneity of the reservoirs.
\end{abstract}

Keywords: diagenesis; authigenic minerals; reservoir quality; Eboliang; Qaidam Basin

\section{Introduction}

Reservoir quality is considered a key control on hydrocarbon migration and accumulation and is ultimately a decisive factor for effective hydrocarbon exploration and production projects [1-4]. 
Consequently, quantitative evaluation of reservoir quality is important to obtain a detailed understanding of reserve estimations and productivity improvement [5-7]. However, the reservoir quality and heterogeneity have been strongly affected by various parameters, such as depositional parameters (e.g., primary depositional textures, detrital composition, grain size and sorting) and different types and sequences of diagenesis [8-10]. Depositional parameters have a significant effect on primary reservoir quality (i.e., porosity and permeability) and consequently on diagenetic alteration, which, in turn, results in complex spatial and temporal patterns of reservoir quality and heterogeneity [11-14]. Diagenesis, including physical processes of mechanical compaction and chemical action of mineral dissolution and precipitation, has a great influence on subsequent evolution paths of porosity and permeability [15-17]. According to burial history and depositional composition, the porosity of shallow sandstone with little cementation can be accurately predicted $[18,19]$. However, under a deeper burial environment, porosity is much more difficult to predict because of the import and export of materials related to dissolution and precipitation of minerals involved in chemical diagenesis $[18,20]$. Therefore, a comprehensive understanding of the diagenesis process of dissolution and precipitation of cements and the origin and sources of minerals are the key to predicting the quality of deeply buried sandstone.

Minerals, including carbonate cements, quartz cements and clay cements, are widely distributed in the clastic reservoirs and have been extensively concerned in the hydrocarbon exploration [21,22]. Formation and transformation of minerals are sensitive to the change of diagenetic fluid properties, which can record the information of diagenetic environment and reveal the mechanism of fluid-rock interaction [23]. In addition, fluid-rock interaction, especially the precipitation and dissolution of carbonate cement, the origin and sources of quartz cement and clay minerals, is of great significance for evaluating and predicting reservoir performance and porosity evolution [24,25]. Qaidam Basin, one of the most petroliferous basins in China, is located in western China (Figure 1a). The Eboliang area in the north of the basin, which comprises a significant structural belt and is a major target for hydrocarbon exploration and development [26]. However, to date, exploration in Eboliang has been limited because the main controlling factors of the reservoir quality have not been thoroughly studied, and only a few studies have been conducted on the Lulehe sandstone mainly focusing on different aspects, including sedimentary facies [27], heavy mineral characteristics and source analysis of the depositional environment [28-32]. These previous studies have shown that the Lenghu area is adjacent to source rocks, with sufficient oil sources in contact with sandbodies, and has become a key area for extended exploration at the north margin of the Qaidam Basin. Moreover, previous studies have also confirmed that the variations in porosity and permeability are mainly due to the development of carbonate cement, authigenic quartz cementation and clay minerals, which indicates that diagenetic alteration is the primary control on reservoir quality. Various types and generations of minerals are present in the Eboliang area [28-32], providing an excellent example to study the fluid-rock interaction and porosity evolution. However, little attention has been paid to the diagenesis and origin and source of the major cements and authigenic minerals in this area, which results in an increased risk of improving the accuracy of reservoir quality evaluation and prediction. Therefore, it is important to have a detailed understanding of origin and sources of minerals and their impact on the hydrocarbon reservoir quality.

Given a recent increase in petroleum exploration in the Eboliang region, factors that affect oil and gas exploration (e.g., the diagenetic alteration characteristics and reservoir quality) have become important areas of focus. In this regard, by integrating sandstone diagenesis with detrital composition, burial history, thermal history, and fluid inclusion and stable isotope analyses of cements, a multidisciplinary approach is developed to carry out a systematic investigation into origin and sources of minerals and their impact on reservoir quality of the Lulehe sandstone in the Eboliang area. Such an approach will provide important insights into the evolution of diagenetic patterns of sandstone, and ultimately improve our ability to understand and predict the evolution of reservoir quality. Thus, the main objectives of this study are to (1) investigate the main diagenetic minerals and 
identify the origin and source of cements and clay minerals; (2) analyze the evolution of diagenesis and reconstruct the history and paragenetic sequences of diagenesis; and (3) identify how difference in diagenetic alteration impact reservoir quality.



Figure 1. Sketch maps showing (a) location of the Qaidam Basin in NW China; (b) major structural units and location of the study area within the Qaidam Basin; and (c) tectonic structures and wells in the study area (modified after Sun [27]). EBL: Eboliang structure; LH: Lenghu structure; MB: Mabei structure; NBX: Nanbaxian structures.

\section{Geological Setting}

The Qaidam Basinis is a large intra-continental sedimentary basin, with a total area of approximately $120,000 \mathrm{~km}^{2}$, located on the northeastern margin of the Tibetan Plateau [31-34]. The basin is a Mesozoic-Cenozoic continental hydrocarbon basin [27] with an irregular rhombic shape and is bounded by three mountain systems: the Altun Mountains to the northwest, the Qilian Mountains to the northeast and the Kunlun Mountains to the south (Figure 1b). With respect to administrative division, the basin is divided into ten first-order structural units: the Saikun Depression, the Yilingping Sag, the Dafengshan Uplift, the Manya Sag, the Kunbei Depression, the Mahai Uplift, the North Slope, the Sanhu Sag, the South Slope, and the Delingha Depression (Figure 1b). The northwest basin fault block belt is located in the southern region of the Qilian Mountains, mainly in the Yilingping Sag, and contains the Eboliang (Figure 1c) and Lenghu structural belts, along with the Mahai and Nanbaxian structures. Due to tectonic evolution, I, II, and III Eboliang structural belts developed from northwest to southeast (Figure 1c) and interbedded main source rocks contain abundant oil and gas source [27]. There is a strong relationship between generation-migration and the Eboliang structure, and the region is a target for commercial hydrocarbon flow.

Stratigraphic development extends from the Paleogene-Neogene-Quaternary, and in ascending order [21], consists of the Paleogene Lulehe Formation $\left(E_{1+2}\right)$, the Lower $\left(E_{3}{ }^{1}\right)$ and Upper $\left(E_{3}{ }^{2}\right)$ Xia Ganchaigou Formation, the NeogeneShang Ganchaigou Formation $\left(\mathrm{N}_{1}\right)$, the Lower $\left(\mathrm{N}_{2}{ }^{1}\right)$ and Upper $\left(\mathrm{N}_{2}{ }^{2}\right)$ Youshashan Formation, the Shizigou Formation $\left(\mathrm{N}_{2}{ }^{3}\right)$ and the Quaternary Qigequan Formation $\left(Q_{1+2}\right)$, as shown in Figure 2. The Paleogene-Neogene ancient lake basin of Qaidam Basin underwent three evolutions stages [26]: the ancient lake basin first appeared in $\mathrm{E}_{1+2}$ period; subsequently, the paleolake expanded continuously from $\mathrm{E}_{1+2}$ to the $\mathrm{N}_{1}$ period, and reached the maximum surface in the subsidence stage of the $\mathrm{N}_{1}$ period; then, the paleolake gradually shrankduring the $\mathrm{N}_{2}{ }^{1}$ to $\mathrm{N}_{2}{ }^{3}$ period. The development center was located in the western part of the Qaidam Basin in the Paleogene and migrated to the Yiliping area during the Miocene to Pliocene [35]. Core analysis 
statistics show that the Paleogene Lulehe Formation $\left(\mathrm{E}_{1+2}\right)$ mainly consists of dark-gray mudstones and interbedded gray fine silt and argillaceous siltstone deposited in alluvial fan and fluvial-deltaic sedimentary environments [26,27].

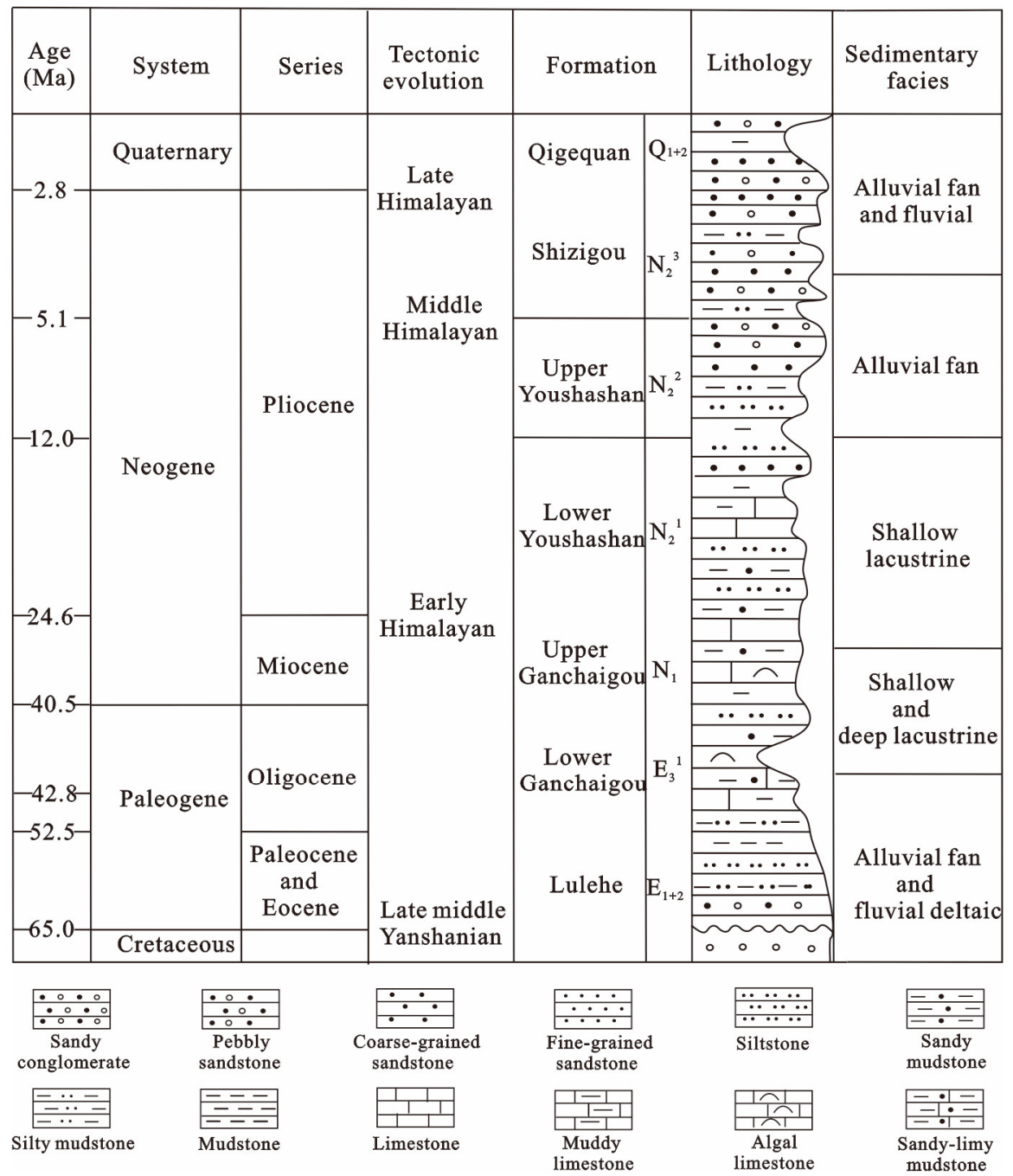

Figure 2. Generalized stratigraphic column for the northwestern Qaidam Basin. Figure after Feng [26].

Burial and thermal history of the Lulehe Formation have been analyzed in detail using data from wells, the history of regional erosion and heat flow was reconstructed with the BasinMod software by previous studies [31-34]. During Lulehe period, the formation shows a progressive subsidence, and the maximum burial depth occurs at approximately $4500 \mathrm{~m}$ (Figure 3). Previous studies indicated that the geothermal gradient of the Lulehe Formation ranges from $25^{\circ} \mathrm{C} / \mathrm{km}$ to $27.5^{\circ} \mathrm{C} / \mathrm{km}[34]$, and the present-day average surface temperature is $10^{\circ} \mathrm{C}$; thus, the highest temperature is approximately $110-125^{\circ} \mathrm{C}$ with a maximumburied depth of $4500 \mathrm{~m}$. 


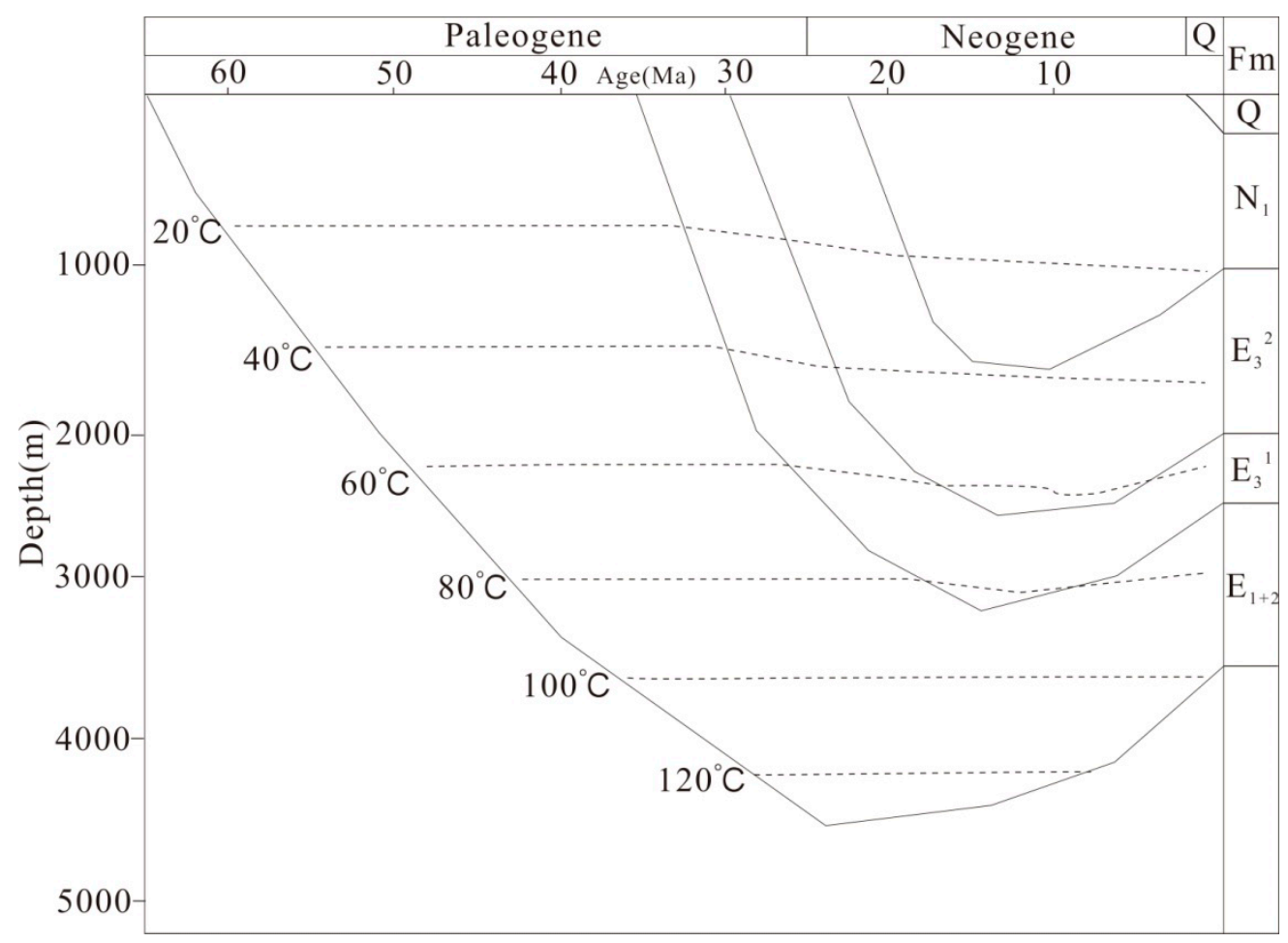

Figure 3. Burial and thermal historiesof the Paleogene Lulehe Formation $\left(\mathrm{E}_{1+2}\right)$. Figure after Li [34].

\section{Samples and Methods}

More than 160 core samples were collected from sections of the Lulehe Formation in the Eboliang area and were derived from more than 30 wells. Quantitative determination of porosity and permeability were made by a $\mathrm{CMS}^{\mathrm{tm}}-300$ Core Measurement system. The mineralogy and structure of selected samples were described based on optical microscope observations of thin sections. The thin sections were prepared by vacuum impregnation with blue epoxy and stained with Alizarin Red S and potassium ferricyanide to facilitate petrographic recognition of visual porosity and identification of rock mineralogy such as dolomites, ferroan calcite, and nonferroan calcite. The samples for compositional analysis were based on 300 points, and petrographic image modal analysis was used to determine the percentage of framework, matrix, cement and porosity in the samples.

A Philips XL 20 scanning electron microscope (SEM, Philips, Amsterdam, The Netherland) equipped with a digital imaging system (Version I) was used to image pore structures, authigenic mineralogy, cements, clay occurrence and paragenetic relationships. The SEM samples were prepared from freshly broken rock fragments coated with gold and analyzed under an acceleration voltage of $20 \mathrm{kV}$ using a beam current of $33 \mathrm{~mA}$. Back scattered electron (BSE) images were also used to determine the relative timing of mineral growth and textural relationships between diagenetic phases. A cathodo-luminescence (CL) detector containing an Olympus microscope equipped with a CL8200-MKS $\mathrm{CL}$, with a beam voltage of $17 \mathrm{kV}$ and a current of $600 \mathrm{~mA}$, was used to help differentiate carbonate and quartz cement. X-ray diffraction (XRD) analyses of more than 30 samples were performed using a Dmax $12 \mathrm{~kW}$ powder diffractometer for clay mineralogy identification. Clay mineral fractions $<2 \mu \mathrm{m}$ were obtained by centrifugation of clay slurries, and each sample was air-dried, glycol-saturated, and heated to $550^{\circ} \mathrm{C}$.

The carbonate cements in 26 representative organic matter free sandstones samples were selected for analysis of the carbon and oxygen stable isotope compositions. These samples were dissolved in phosphoric acid $\left(\mathrm{H}_{3} \mathrm{PO}_{4}\right)$, and the evolved $\mathrm{CO}_{2}$ gas was analyzed for carbon and oxygen isotopes in a Finnigan MAT 253 isotope ratio mass spectrometer (Thermo Fisher Scientific, Waltham, MA, USA). The carbonate cements samples that reacted with $100 \%$ phosphoric acid $\left(\mathrm{H}_{3} \mathrm{PO}_{4}\right)$ at $25{ }^{\circ} \mathrm{C}$ for one 
hour (calcite), at $50^{\circ} \mathrm{C}$ for $24 \mathrm{~h}$ (Fe-dolomite/ankerite), respectively. The precision of the carbon and oxygen isotope ratios were $\pm 0.04 \%$ ond $\pm 0.06 \%$, respectively. The carbon and oxygen isotope data are presented in the $\delta$ notation relative to the Vienna Pee Dee Belemnite (V-PDB) standards. Six core samples were prepared by doubly polished fluid inclusion wafers for observation of fluid inclusion and microthermometric measurements. Microthermometry was conducted using calibrated Linkam A TH-600 heating and cooling stages (Linkam, Epsom, UK) of fluid inclusions, and the phase transition temperature range can be measured from $180{ }^{\circ} \mathrm{C}$ to $500{ }^{\circ} \mathrm{C}$ with an accuracy of \pm 0.1 to \pm 1.0 . The chemical composition of the carbon-coated, polished thin sections of carbonate cements was analyzed by a JEOLJXA-8100 electron microprobe analyzer (EMPA) (JEOL, Tokyo, Japan) under an accelerating voltage of $20 \mathrm{kV}$ with a beam current of $15 \mathrm{nA}$.

All the core samples and statistical data from wells were collected from the Petroleum Exploration and Production Research Institute of Qinghai Oilfield Company, PetroChina. Point counting, fluid inclusion, and optical and scanning electron microscopy analyses were performed at the laboratory of PetroChina Qinghai Oilfield Company (Qinghai, China). XRD was conducted in the Micro Structure Analytical Laboratory, Beijing, China. The carbon and oxygen isotopic and chemical composition analyses of carbonate cements were conducted at the key laboratory of Petroleum Resources Research, Institute of Geology and Geophysics, Chinese Academy of Sciences (Lanzhou, China).

\section{Results}

\subsection{Sandstone Petrography}

\subsubsection{Detrital Composition and Texture}

The Lulehe Formation sandstones are primarily composed of brown mudstones, gray fine siltstone, argillaceous siltstone and fine sandstone (Figure 4a). The sandstones are predominantly classified as feldspathic litharenites and lithic arkose according to the classification by Folk [36] (Figure 4b). Overall, the petrographic framework compositions of the studied sandstones are immature. Quartz is the most common detrital constituent, with monocrystalline quartz ranging from $13 \%$ to $79 \%$, with an average value of $47.9 \%$, and polycrystalline quartz ranging from $0.3 \%$ to 12.6 , with an average value of $5.7 \%$. Feldspar consisting of both plagioclase and K-feldspar varies from $12 \%$ to $36 \%$ and averages $18.6 \%$, while the K-feldspar is the dominant type of the feldspar. In addition, the rock fragment volume fraction ranges from $3 \%$ to $52 \%$, with an average of $22.7 \%$, primarily consisting of metamorphic rock debris and volcanic rock grains. Other detrital grains include micas, biotite, muscovite, heavy minerals (garnet, zircon, rutile) and mud intraclasts. On average, the sandstones are mainly composed of subangular to subrounded grains, most of which are in linear to concave-convex contacts, thus indicating moderate to poor sorting (Figure 4c).


Figure 4. Rock composition lithology and sorting distribution of the Lulehe Formation sandstone reservoirs: (a) Lithology distribution; (b) Ternary diagram illustrating the classification of sandstone on base of Folk's [36] classification; (c) Sorting distribution. 


\subsubsection{Reservoir Physical Characteristics}

According to conventional core analysis of more than 160 plugs sampled from the Lulehe Formation, the porosity and permeability of sandstone vary widely. A statistical analysis shows that the porosity ranges from $1.69 \%$ to $31.33 \%$, with an average of $9.65 \%$ (Figure 5a), whereas the permeability ranges from 0.03 to $366.52 \mathrm{mD}$, with an average of $13.75 \mathrm{mD}$ (Figure 5b). In general, the porosity and permeability of the Lulehe sandstones decrease with progressive burial but slightly increase in some depth intervals (300-3200 m, 3400-3600 m and 4000-4100 m respectively) (Figure 5a,b). The petrographic microscopy and SEM analyses revealed that depositional primary and diagenetic secondary pores are both present. Depositional primary pores mainly include residual intergranular pores (Figure $6 \mathrm{a}-\mathrm{c}$ ), while diagenetic secondary pores can be subdivided into dissolution pores (e.g., intergranular and intragranular dissolution pores), with minor amounts of microfractures (Figure 6d). In addition, point count thin section porosity is generally consistent with core plug porosity, but in most cases, thin section porosity is lower than core plug porosity, indicating the presence of micro-pores within the clay minerals (Figure 6a,c). The statistical analysis data show that diagenetic secondary pores (average $36 \%$ in the total porosity) are more abundant than depositional primary pores (up to $62 \%$ ), suggesting that diagenesis plays an important role in the modification of the reservoir pores and properties.

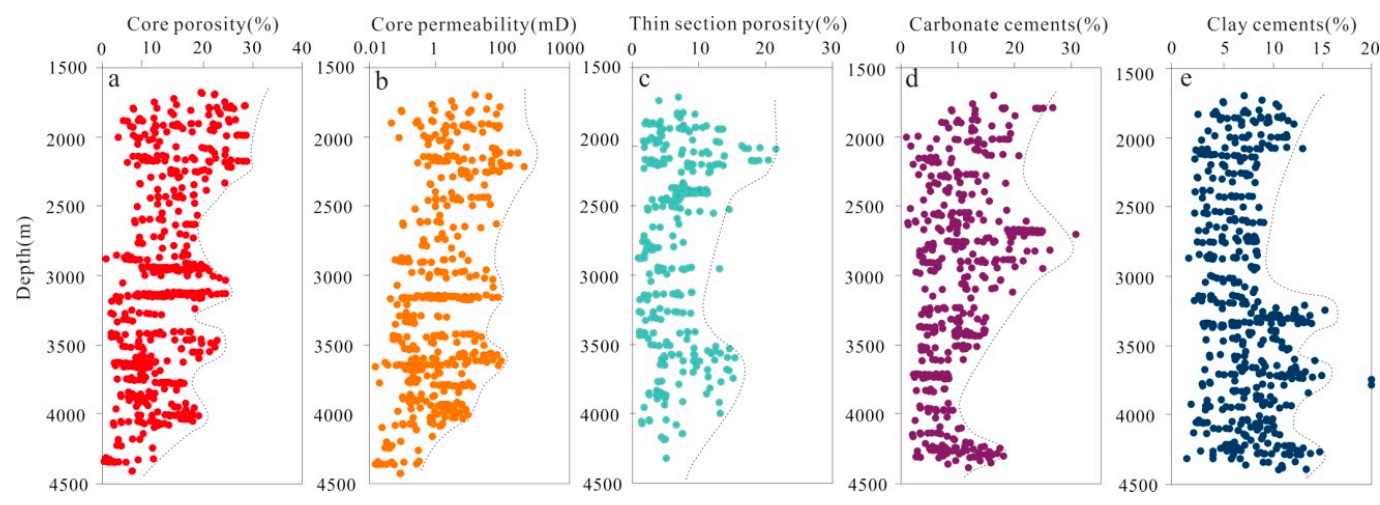

Figure 5. Plot showing variations of (a) core porosity; (b)core permeability; (c) thin section porosity; (d) carbonate cement; (e) and clay cementswith respect to depth.

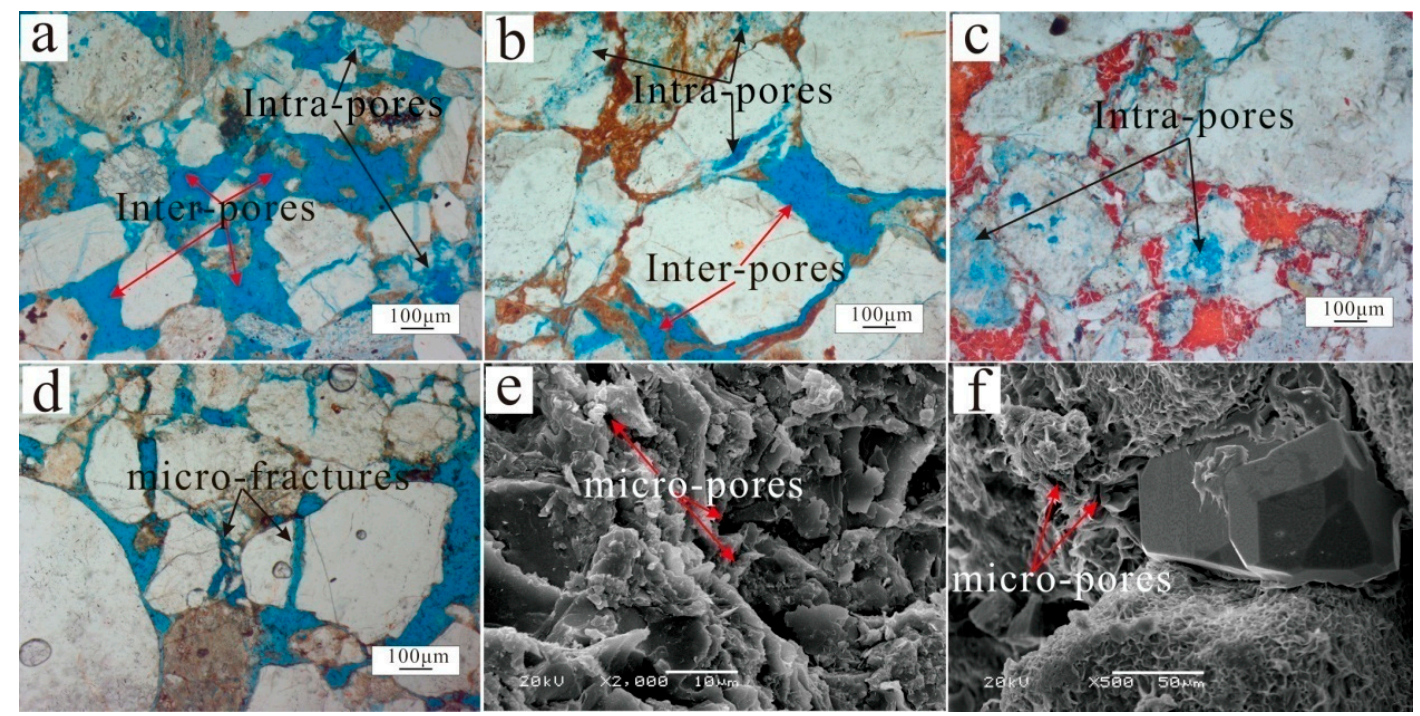

Figure 6. Pore types (a-f) in Lulehe sandstones reservoir. Inter-pores: intergranular pores; Intra-pore: intragranular pores. 


\subsection{Diagenetic Alteration Features}

The petrographic and XRD as well as SEM analyses of the samples revealed complicated diagenetic alteration. The major diagenetic processes that controlled the reservoir properties include compaction, cementation by carbonate and quartz, authigenic clay minerals and dissolution of unstable materials.

\subsubsection{Compaction}

Compaction is one of the most important types of diagenesis in reservoirs, and it can be subdivided into mechanical and chemical compaction, which occurs widely in the Lulehe sandstones. Mechanical compaction is identified by grain rearrangement (Figure 7a) and deformation of argillaceous detritus, mica, and other ductile grains (Figure 7b), sometimes resulting in the formation of a pseudomatrix (Figure 7c). However, there is also evidence for deep burial depth, during which chemical compaction plays a major role. In this case, grain contacts are dominated by long contacts and concavo-convex contacts (Figure 7d). Furthermore, sutured contacts were occasionally observed in the thin sections (Figure 7e,f), implying the occurrence of chemical compaction in the Lulehe sandstone. In addition, the compaction effect was more intense in the samples containing more ductile fragments (e.g., clay matrix, mica and volcanic fragments) but was relatively weak in the samples with high quartz content and good sorting.



Figure 7. Thin-section photomicrographs showing compaction and calcite cement features. (a) Grain contacts present dominated by linear types (yellow arrow) due to the influence of compaction, cross-polarized light (CPL). (b) Mechanical compaction is identified by deformation of mica, plane-polarized light (PPL). (c) Deformation of mica and ductile grains resulting in the formation of a pseudomatrix (yellow arrow), CPL. (d) Grain contacts characterized by long contacts (yellow arrow), PPL. (e) Grain contacts characterized by long and concavo-convex contacts (yellow arrow), PPL. (f) Chemical compaction evidenced by grain rearrangements with concavo-convex contacts (yellow arrow), PPL. (g) Calcite cements filling between loosely packed grains, PPL. (h) As a result of the amount of calcite cements filling in the pores, the clastic grains appear to be floating, PPL. (i) Calcite cements represented the partial replacement of grains and filling in the intergranular pores, PPL. Cal: calcite. 


\subsubsection{Carbonate Cements}

Carbonate cements (calcite, dolomite, ferroan calcite, ankerite) are the most abundant authigenic minerals in the studied sandstone and range from 0.86 to $32 \%$ of the total rock volume composition (avg. 13.6\%). The EMPA data show that the carbonate cements are dominated by calcite, with the average amounts of $\mathrm{CaCO}_{3}, \mathrm{FeCO}_{3}, \mathrm{MgCO}_{3}$ and $\mathrm{MnCO}_{3}$ being $94.62 \mathrm{~mol} \%, 1.66 \mathrm{~mol} \%, 3.08 \mathrm{~mol} \%$ and $0.65 \mathrm{~mol} \%$, respectively (Table 1), followed by dolomite and a minor amount of ferroan calcite and ankerite. In addition, at the depth of 2700-2800 $\mathrm{m}$ and 4400-4500 m, there are abnormally high values of carbonate cement content, corresponding to the low values of porosity and permeability (Figure $5 \mathrm{~d}$ ).

Table 1. Element ( $\mathrm{Ca}, \mathrm{Fe}, \mathrm{Mg}$ and $\mathrm{Mn}$ ) content of carbonate cements in the Lulehe sandstones.

\begin{tabular}{|c|c|c|c|c|c|c|c|c|c|c|c|}
\hline \multirow[t]{2}{*}{ Sample } & \multirow{2}{*}{$\begin{array}{l}\text { Depth } \\
\text { (m) }\end{array}$} & \multirow{2}{*}{$\begin{array}{l}\text { Analyzed } \\
\text { Spot }\end{array}$} & \multicolumn{5}{|c|}{ Content (in wt. \%) } & \multicolumn{4}{|c|}{$\begin{array}{c}\text { Content (in mol\%, Normalized } \\
\text { with Calcium to } 100 \mathrm{~mol} \% \text { ) }\end{array}$} \\
\hline & & & $\mathrm{CaO}$ & $\mathrm{FeO}$ & $\mathrm{MgO}$ & $\mathrm{MnO}$ & Total & $\mathrm{Ca}$ & $\mathrm{Fe}$ & $\mathrm{Mg}$ & Mn \\
\hline ES-I2 & 4216.82 & 1 & 53.46 & 0.68 & 1.56 & 0.06 & 55.76 & 94.13 & 1.36 & 4.35 & 0.16 \\
\hline ES-I2 & 4313.35 & 1 & 54.48 & 0.17 & 0.62 & 0.03 & 55.30 & 97.98 & 0.26 & 1.63 & 0.13 \\
\hline ES-I2 & & 1 & 54.38 & 1.21 & 2.11 & 0.46 & 58.16 & 91.96 & 1.89 & 5.46 & 0.69 \\
\hline ES-I2 & & 2 & 52.36 & 0.89 & 0.47 & 0.19 & 53.91 & 97.68 & 0.86 & 0.93 & 0.53 \\
\hline ES-I2 & 4323.58 & 1 & 53.67 & 0.16 & 1.76 & 0.08 & 55.67 & 97.31 & 0.49 & 2.16 & 0.04 \\
\hline ES-3 & 3622.05 & 1 & 54.76 & 3.21 & 3.86 & 0.96 & 62.97 & 83.32 & 5.63 & 9.87 & 1.18 \\
\hline ES-3 & & 1 & 54.46 & 1.18 & 0.68 & 0.67 & 56.99 & 94.41 & 2.02 & 2.45 & 1.12 \\
\hline ES-3 & 3623.30 & 2 & 53.68 & 0.97 & 1.37 & 0.14 & 56.16 & 94.71 & 1.31 & 3.72 & 0.26 \\
\hline ES-3 & & 1 & 54.37 & 1.28 & 1.35 & 0.62 & 57.62 & 93.25 & 1.76 & 3.76 & 1.23 \\
\hline ES-3 & 3627.63 & 2 & 53.67 & 0.65 & 0.49 & 0.03 & 54.84 & 97.44 & 0.98 & 1.06 & 0.52 \\
\hline ES-3 & 3631.18 & 1 & 54.35 & 1.02 & 1.16 & 0.76 & 57.29 & 96.10 & 1.36 & 1.68 & 0.86 \\
\hline ES-3 & 3632.57 & 1 & 53.69 & 1.32 & 1.25 & 0.67 & 56.93 & 95.27 & 1.98 & 1.86 & 0.89 \\
\hline LS-1 & 2810.23 & 3 & 53.96 & 1.98 & 1.16 & 0.36 & 57.46 & 95.13 & 1.73 & 2.46 & 0.68 \\
\hline LS-1 & 2813.65 & 1 & 54.39 & 0.96 & 0.68 & 0.32 & 56.35 & 96.60 & 1.46 & 1.49 & 0.45 \\
\hline LS-1 & 2820.34 & 2 & 54.36 & 1.16 & 1.53 & 0.68 & 57.73 & 93.97 & 1.76 & 3.25 & 1.02 \\
\hline
\end{tabular}

There are two types of calcite in the Lulehe reservoir sandstone, calcite (Ca-I) is dominated bycoarse-crystalline calcite occurs as coarse crystalline poikilotopic, pore-filling blocky, and aggregate pore-filling forms $(10-400 \mu \mathrm{m})$. Conversely, another type of calcite (Ca-II) occurs as micritic to microcrystalline and was in close contact with detrital grains, the different textures of calcite ments suggest they may precipitation in various diagenetic regimes [15]. Calcite (Ca-I) have presumably formed near the sediment-water interfaceduring early diagenesis (shallow burial realm), as evidenced by fills relatively large pores between loosely packed framework grains or represented the partial replacement of grains (Figure $7 \mathrm{~g}-\mathrm{i}$ ), suggests that formed pre-dates significant mechanical compaction in shallow depth. However, dense micritic texture calcite (Ca-II) filled the gaps between tightly packed grains and covers and engulfs quartz overgrowths (Figure 8a), and is interpreted to have precipitated post-dates quartz overgrowths which was commonly occur in mesogenetic stage (deep burial realm). Moreover, based on the BSE and CL image, calcite cements also occur as partial grain replacements, locally replacing feldspar, lithic grains or mica (Figure $8 b, c)$, and some of the calcite cements appear in a circular band (Figure 8d). In addition, dolomite cements generally fill in intergranular pores between floating grains (Figure 8e), indicating that the cements formed before intense compaction during early diagenesis. Ferrocalcite and ankerite typically occur as scattered patchy crystals or euhedral rhombs $(20-150 \mu \mathrm{m})$ and are minor cements, they usually fill in feldspar dissolution pores and replace detrital grains or calcite and dolomite (Figure 8f), indicating that the ferrocalcite and ankerite formed post-datescalcite and dolomite cements and feldspar dissolution, and is can be inferred that it have precipitated in mesogenetic stage during deep burial depth. 


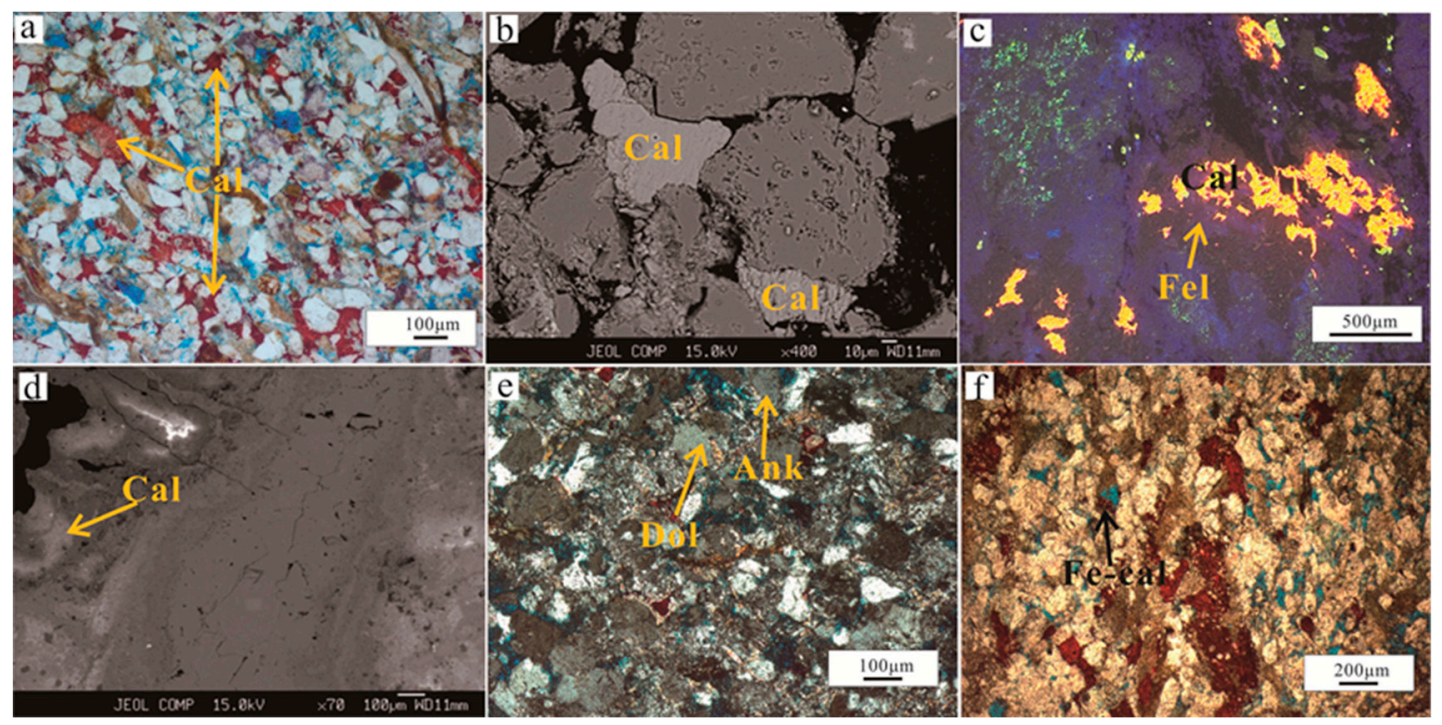

Figure 8. Photomicrographs showing the characteristics of carbonate cementation (a) Dense micritic texture calcite (Ca-II) filled the gaps between tightly packed grains and covers and engulfs quartz overgrowths (yellow arrow), PPL. (b) Backscattered electron (BSE) image of isolated pore-filling carbonate cement. (c) CL image showing calcite cements locally replacing feldspar. (d) BSE image showing pore-filling calcite cements appear in a circular band. (e) Dolomite and ankerite cement occur mainly as isolated rhombic and euhedral rhombs crystals, respectively. (f) Ferrocalcite filling in feldspar dissolution pores and replace detrital grains (black arrow), PPL. Cal: calicite; Fel: Feldspar; Dol: Dolomite; Ank: Ankerite; Fe-cal: Ferrocalcite.

\subsubsection{Quartz Cements}

Thin section and SEM analyses revealed that quartz cements are common and observed constituting $0.3-8.36 \%$ (avg. $3.8 \%$ ) of the total rock volume and mainly occurs as syntaxial overgrowths around detrital quartz grains (quartz overgrowths, thickness of 20-200 $\mu \mathrm{m}$ ). Some examples of authigenic quartz occurring as euhedral and hexagonal crystals partially or completely infilling intergranular pores (Figure 9a) were observed but represent a relatively minor amount. In most cases, quartz overgrowths can be discriminated from the detrital grains due to the existence of dust rims or clay mineral coatings and fluid inclusions, with pores often engulfed by large syntaxial overgrowths (Figure $9 \mathrm{~b}-\mathrm{d}$ ). However, quartz overgrowths were inhibited by localized chlorite grain coating. In contrast, Quartz overgrowths were also observed where chlorite rims and grain coating are absent or rare, with thicknesses of $\sim 20-200 \mu \mathrm{m}$ and regularly varying morphology (Figure 9e). In other words, only continuous chlorite rims or a certain thickness of chlorite grain coating can delay and inhibit the quartz overgrowths. Quartz overgrowths are usually associated with feldspar dissolution (Figure 9f) and engulfed by ferroan calcite and ankerite cements, indicating that the quartz cement postdates feldspar dissolution but predates the ferroan calcite and ankerite cements. Quartz cement is more abundant in the matrix-rich sandstones, which are mainly poorly sorted, fine-grained sandstones. 


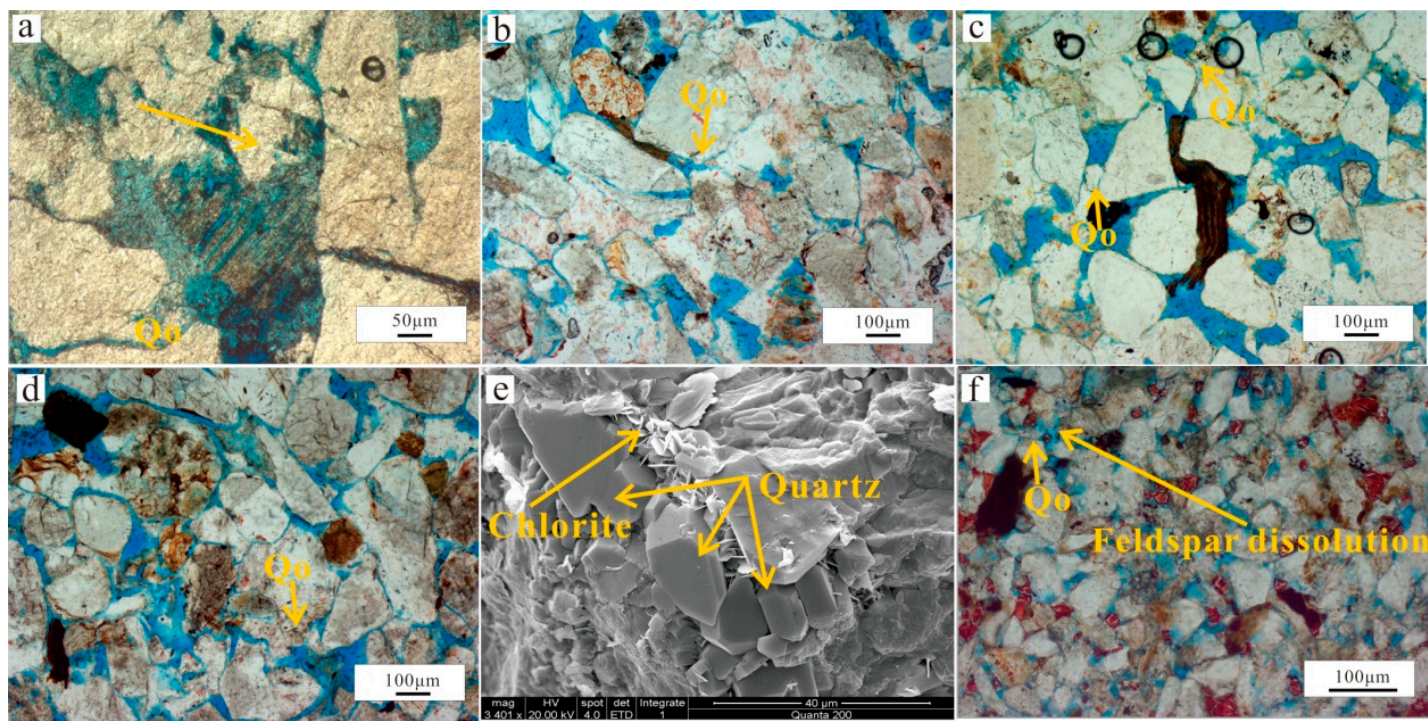

Figure 9. Photomicrographs showing characteristics of quartz cements. (a)Authigenic quartz occurring as euhedral crystals partially infilling intergranular pores (yellow arrow), PPL. (b) Quartz overgrowths can be discriminated from the detrital grains due to the existence of dust rims, PPL. (c) Quartz overgrowths occluding the pore space, PPL. (d) Pores space engulfed by quartz syntaxial overgrowths, PPL. (e) Quartz overgrowths due to discontinuous chlorite. (f) Feldspar dissolution was accompanied by quartz overgrowths. Qo: Quartz overgrowths.

\subsubsection{Clay Cements}

Four main clay mineral types (Figure 10) were observed via thin section petrography, SEM and XRD analyses ranging from $2 \%$ to $20 \%$ of the total rock volume (average $5.6 \%$ ). Illite is the most abundant diagenetic constituent, accounting for $16 \%$ to $78 \%$ (average $62.87 \%$ ) of the total clay content, followed by chlorite (average 15.16\%), illite-smectite (average 13.69\%) and kaolinite (average 8.27\%). The content of clay minerals increased with the depth (Figure 5e), but the variation trend of various clay minerals was different. XRD data of clay minerals in the Lulehe sandstone show that illite dominates in sandstones with depth deeper than 3300m (Figure 9a), whereas the content of kaolinite increased significantly above $3330 \mathrm{~m}$ (Figure 10b). The mixing layer of illite and smectite increased with the depth (Figure 10c), while the content of smectite in the mixing layer of illite and smectite decreased with the depth (Figure 10d). Chlorite tends to decrease with increasing depthand mainly concentrated above 3000m (Figure 10e).

In general, honeycomb-like crystals of illite-smectite and fibrous illite are the major clay cements and are widely distributed. In some cases, illite-smectite occurs as a replacement product of detrital micas and fills in pores as pore-filling clay. Furthermore, the thickness of the illite coating can be up to $50 \mu \mathrm{m}$, which usually encircles the grain at the place where the intergranular pore develops but rarely occurs at the grain contact. However, the fibrous morphology of illite typically appears as fibrous aggregates that bridge and filling in primary pores and secondary pores (Figure 11a,b). SEM observations also show that irregular flakes with lath-like illite usually attach to the quartz overgrowth surface and fill in the intergranular pores, indicating that quartz overgrowth precedes the precipitation of illite (Figure 11c). 

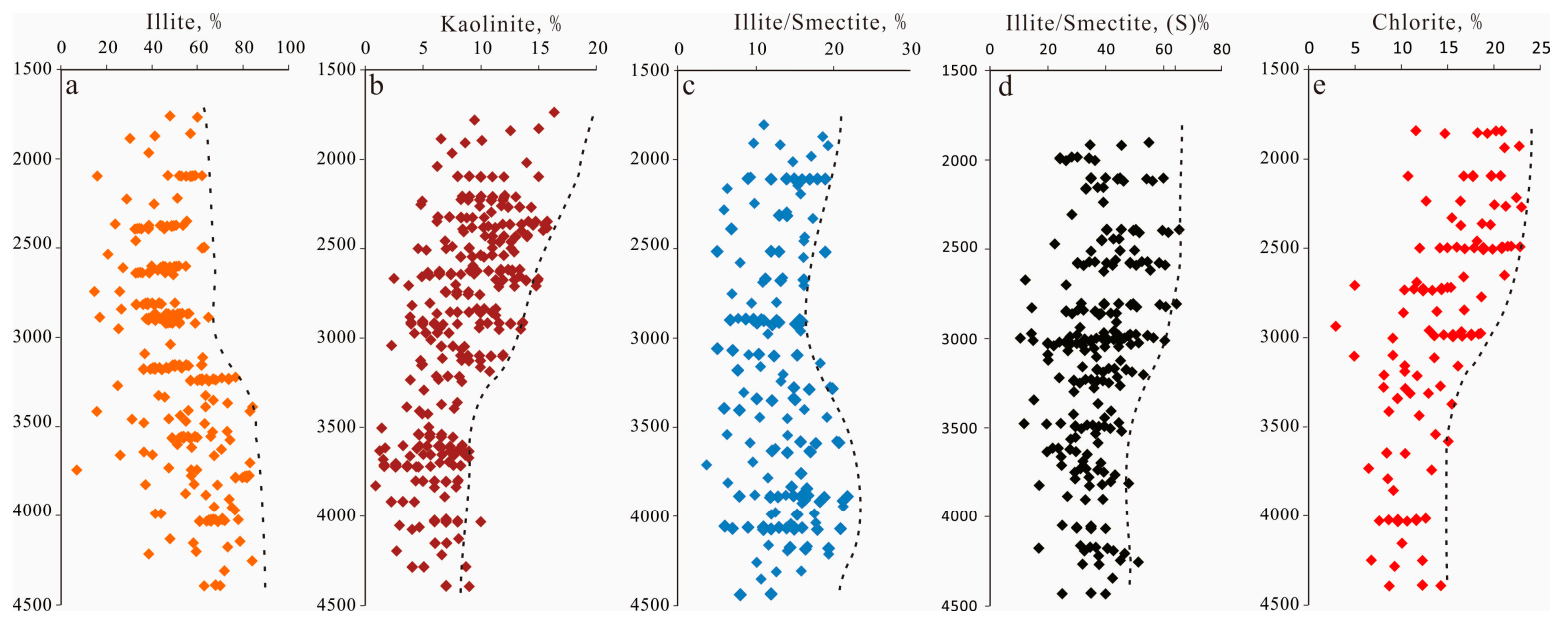

Figure 10. Vertical distribution characteristics of clay minerals in the Lulehe sandstones (From XRD data). (a) Cross plot of illite with depth; (b) Cross plot of kaolinite with depth; (c) Cross plot of mixing layer of illite and smectite with depth; (d) Cross plot of the content of smectite in the mixing layer of illite and smectite; (e) Cross plot of chlorite with depth.

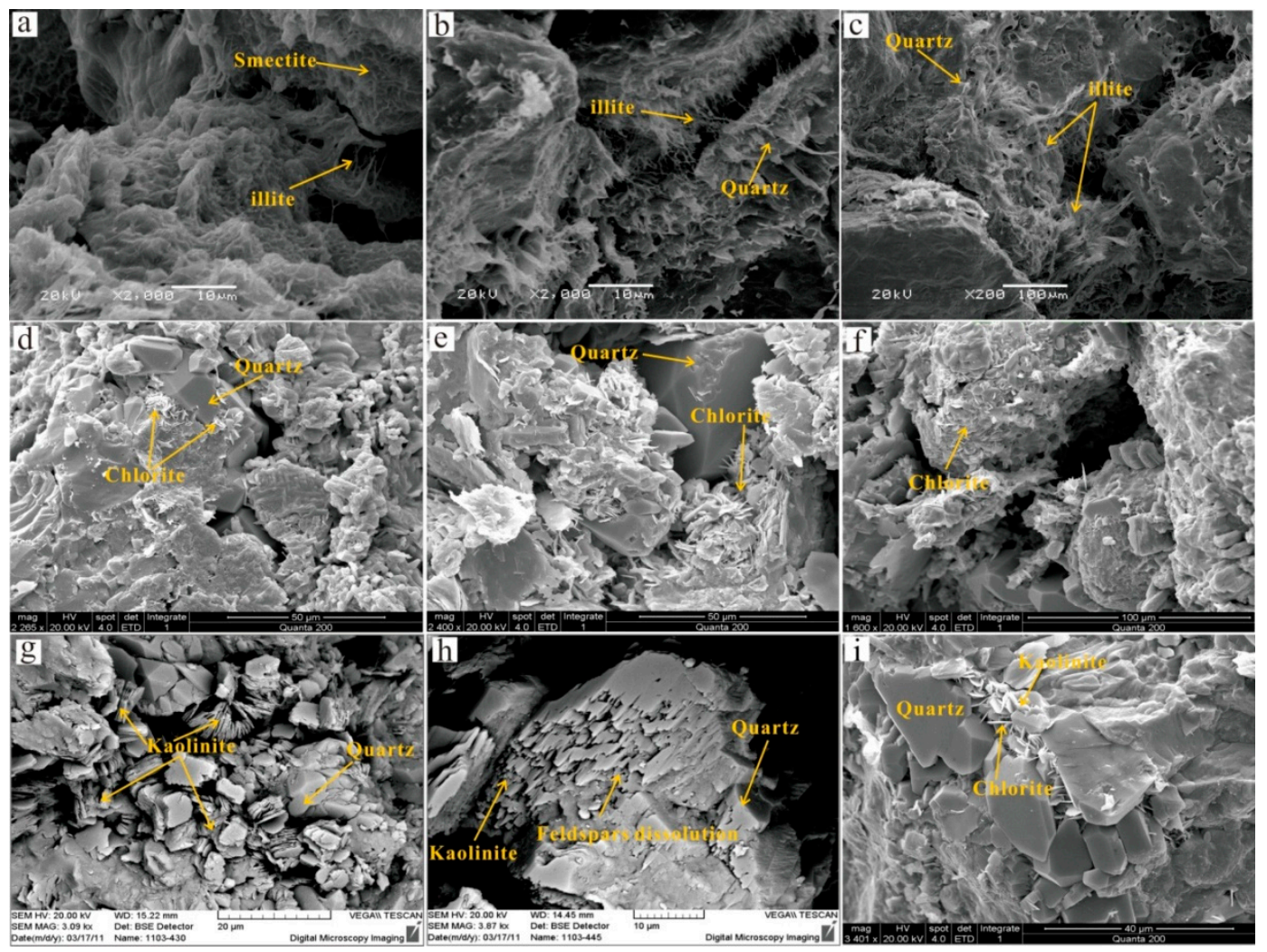

Figure 11. Scanning electron micrographs of sandstones showing characteristics of clay cements. (a) Pore filling illite and smectite. (b) Fibrous morphology of illite typically appears as fibrous aggregates that bridge and filling in pores. (c) Irregular flakes with lath-like illite usually attach to the quartz overgrowth. (d) The pore-lining chlorite occurs locally as irregular needle crystals perpendicular and parallel to the quartz grain surfaces. (e) Pore-filling aggregate chlorite minerals consist of rosette-shaped platelets oriented radially and occluding the intergranular pores. (f) Platelets of authigenic chlorite seem to inhibit quartz overgrowth. (g) Kaolinite occurs primarily as stacks of booklets aggregates. (h) Kaolinite is commonly associated with feldspar grain dissolution and silica precipitation. (i) Platelets of kaolinite that retards the growth of chlorite crystals. 
Chlorite is slightly more abundant than kaolinite and mainly includes grain-coating (pore-lining) chlorite and pore-filling chlorite based on petrographic and SEM image observations. The pore-lining chlorite occurs locally as irregular needle crystals perpendicular and parallel to the detrital grain surfaces (Figure 11d), whereas a minor amount of pore-filling aggregate chlorite minerals consists of rosette-shaped platelets oriented radially and occluding the intergranular pores (Figure 10e). Generally, the quartz grains with discontinuous chlorite rims are locally enclosed by quartz overgrowths (Figure 10d,e), while continuous chlorite coating is generally characterized by a small amount of quartz cementation (Figure 11f). In addition, detrital biotite and igneous rock fragments were observed to be locally replaced by chlorite.

In contrast, kaolinite is generally a minor phase and occurs primarily as stacks of booklets, vermicular aggregates with individual crystals up to $6 \mu \mathrm{m}$ long that sit in intergranular pores (Figure 11g). Kaolinite is commonly associated with feldspar grain dissolution (Figure 11h) and alteration of mica, and mica grains was partially replaced by kaolinite, suggesting that feldspar and mica grains may be a source for the precipitation of kaolinite. Less commonly, kaolinite also occurs as blocky aggregates composed of euhedral and pseudohexagonal plates filling in primary pores, and in the deeply buried areas, high-temperature kaolinite seems to be locally transformed into dickite. SEM images show that kaolinite seems to inhibit the growth of chlorite crystals (Figure 11i); thus, it can be inferred that kaolinite predates the precipitation of chlorite.

\subsection{Mineral Chemistry}

\subsubsection{Stable Isotopes of Carbonate Cement}

The type and contents of carbonate cements were determined on the basis of carbon and oxygen isotopic analysis of thin sections from 31 sandstone samples, which are plotted in Figure 12a. Both the carbon and oxygen isotopes (i.e., Vienna Pee Dee Belemnite normalized isotopes: $\delta^{13} \mathrm{C}_{\mathrm{PDB}}$ and $\delta^{18} \mathrm{O}_{\mathrm{PDB}}$ ) spanned a wide range of values (Table 2). The $\delta^{13} \mathrm{C}_{\mathrm{PDB}}$ values range from $-15.21 \%$ o to $-3.21 \%$, and the $\delta^{18} \mathrm{O}_{\mathrm{PDB}}$ values range from $-21.07 \%$ o to $-11.48 \%$. The $\delta^{13} \mathrm{C}_{\mathrm{PDB}}$ values in the Cal-I cements have a relatively wide range from $-9.84 \%$ o to $-3.21 \%$, with an average value of $-5.63 \%$, and the $\delta^{18} \mathrm{O}_{\mathrm{PDB}}$ values range from $-14.28 \%$ o to $-11.74 \%$, with an average value of $-13.75 \%$ o. Cal-II cements have only sporadic data, the $\delta^{13} \mathrm{C}_{\mathrm{PDB}}$ values range from $-13.78 \%$ o to $-12.86 \%$, and the $\delta^{18} \mathrm{O}_{\mathrm{PDB}}$ values range from $-19.56 \%$ o to $-18.75 \%$ o. Dolomite has a wider range of $\delta^{13} \mathrm{C}_{\mathrm{PDB}}$ values from $-6.70 \%$ o to $-4.37 \%$, with an average value of $-5.18 \%$, and $\delta^{18} \mathrm{O}_{\mathrm{PDB}}$ values from $-13.74 \%$ o to $-11.48 \%$, with an average value of $-12.21 \%$. The $\delta^{13} \mathrm{C}_{\mathrm{PDB}}$ values of ferroan-calcitecements range from $-15.21 \%$ o to $-6.58 \%$, with an average value of $-10.49 \%$, and the $\delta^{18} \mathrm{O}_{\mathrm{PDB}}$ values range from $-20.20 \%$ o to $-16.58 \%$, with an average value of $-18.41 \%$ o. While ankerite cements have a narrow range of $\delta^{13} \mathrm{C}_{\mathrm{PDB}}$ values that range from $-12.84 \%$ o to $-9.38 \%$, with an average value of $-10.81 \%$, and $\delta^{18} \mathrm{O}_{\mathrm{PDB}}$ values that range from $-21.07 \%$ o to $-18.67 \%$, with an average value of $-19.72 \%$ o. 

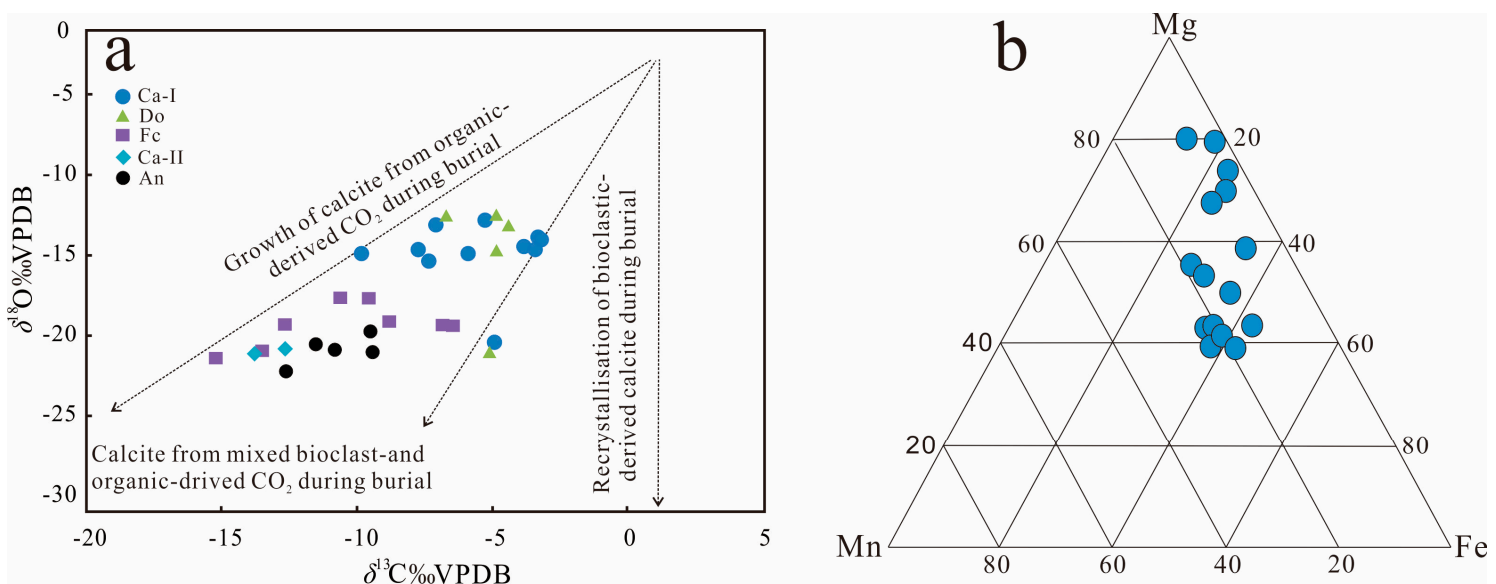

Figure 12. (a) Scatter diagram of $\delta^{13} \mathrm{C}$ and $\delta^{18} \mathrm{O}$ for calcite cements in the Lulehe sandstone reservoirs. The $\delta^{13} \mathrm{C}$ values indicate that sparry carbonate cements were influenced by organic matter (the model modified after Rahman [37]). (b) Ternary plot of Fe-Mg-Mn element compositions of carbonate cements, data from Table 1.

Table 2. Mineralogical and carbon and oxygen isotopic composition of carbonate cements, and calculated formation temperature of carbonate cements in Lulehe sandstone.

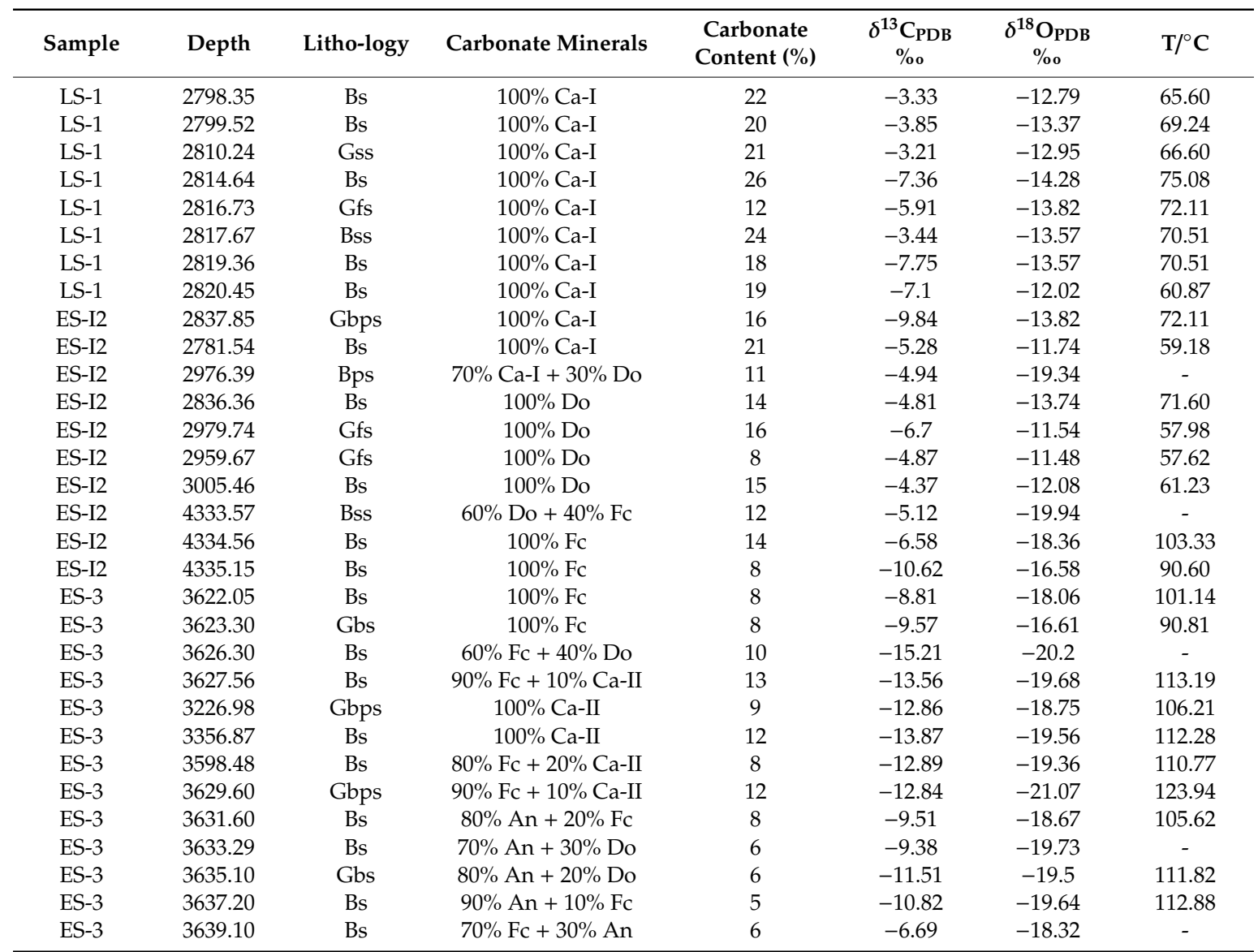

Note: Only isotopic data of samples with the content of one specific type of carbonate up to $80 \%$ were used to calculate the temperature. Bs: Brown sandstone; Gss: Gray silty sandstone; Gfs: Gray fine sandstone; Bss: Brown silty sandstone; Gbps: Gray-brown pelitic siltstone; Bps: Brown pelitic siltstone; Bss: Brown silty sandstone; Gbs: Gray-brown sandstone;Ca:calcite; Do:dolomite; Fc:ferrocalcite; An: ankerite. 


\subsubsection{Fluid Inclusions Analysis}

Fluid inclusions record valuable information for diagenetic events and the precipitation temperature of authigenic minerals [38] and provide pressure-volume-temperature-composition (PVT) information. Therefore, to determine the temperature of the precipitation of the authigenic clay minerals and quartz cements, six core samples were prepared as doubly polished thin sections and were examined for aqueous inclusions, and the fluid inclusions occurring in quartz cements were selected for microthermometric measurements according to the thin section analysis. Most of the selected fluid inclusions had diameters of approximately 2-10 $\mu \mathrm{m}$ and two phases, with only a few single-phase gas inclusions at room temperature.

The homogenization temperatures (Th) were measured for the aqueous inclusions that were trapped during quartz cementation and range from $70-120^{\circ} \mathrm{C}$ (Figure 13). Moreover, the temperatures calculated from $\delta^{18} \mathrm{O}$ in carbonate cements (Ca-II, ferroan calcite and ankerite) range from $-21.07 \%$ o to $-16.58 \%$, thus yield Th ranges from $90-123^{\circ} \mathrm{C}$ (Table 2). The results suggest that precipitation of Ca-II, ferroan calcite, ankerite and quartz cementation mainly occurred in the mesodiagenetic stages, which is consistent with the thin section observations.
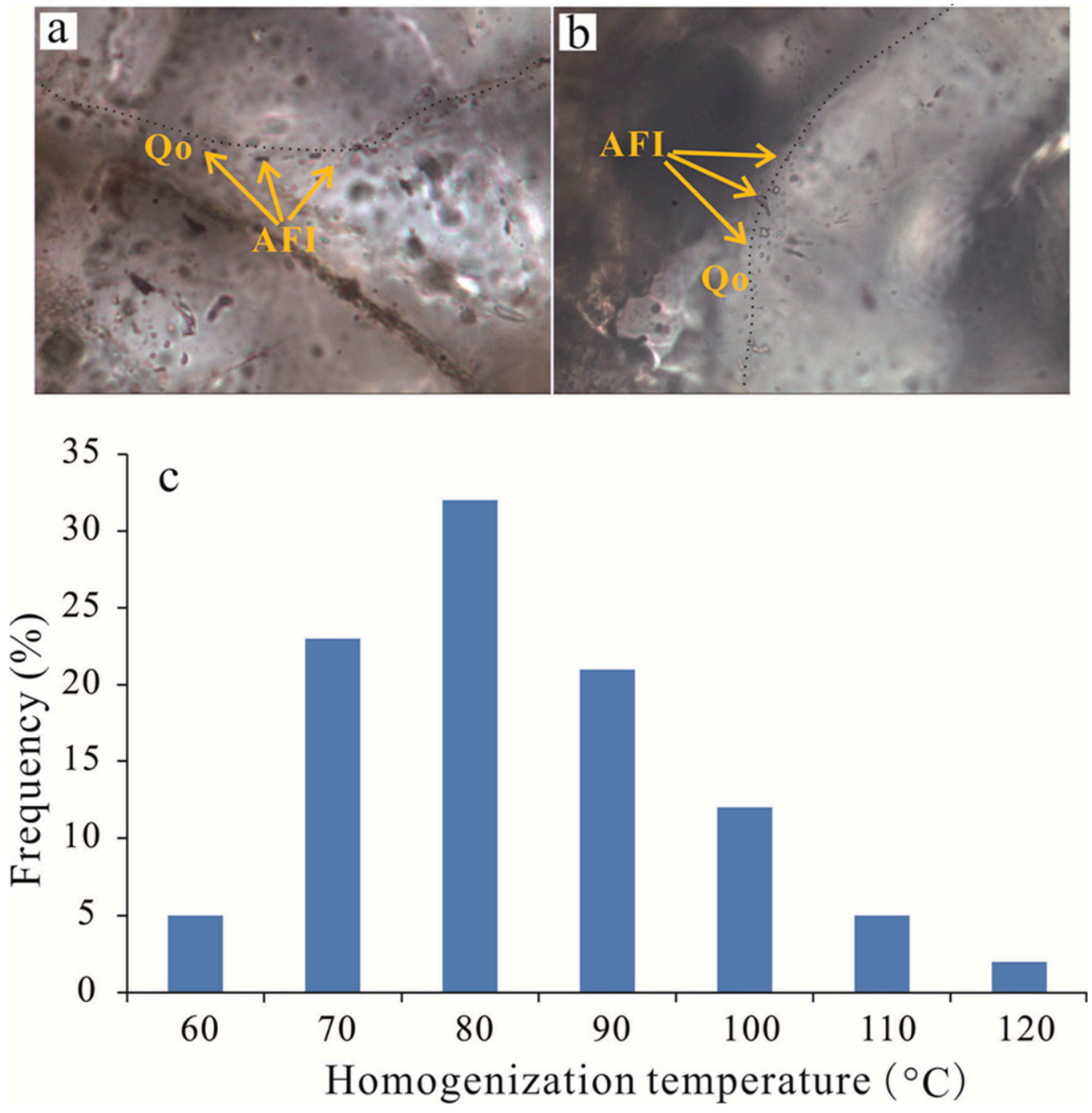

Figure 13. (a,b) Photomicrographs of aqueous fluid inclusions (AFI) in quartz overgrowth (Qo). (c) Histograms of homogenization temperatures (Th) of aqueous inclusions in quartz overgrowths in Lulehe sandstone reservoirs. 


\section{Discussion}

\subsection{Origin and Sources of Carbonate Cements}

Carbonate minerals (calcite, ferroan-calcite, dolomiteand ankerite) are the most common authigenic minerals in the Lulehe sandstones and can be formed by various pathways and multiple diagenetic stages. The divalent cations $\mathrm{Ca}^{2+}, \mathrm{Mg}^{2+}, \mathrm{Fe}^{2+}, \mathrm{Mn}^{2+}$ and carbon dioxide in carbonate cements may exist as internal, external or mixed sources [38-40]. Internal sources include dissolution of detrital anorthite grains, calcretes, carbonate rock fragments, calcite fossil fragments and reworked carbonate intraclasts [41-43]. External sources include compaction drainage and mutual conversion of clay minerals such as illitization of kaolinite and smectite, which will release the $\mathrm{Ca}^{2+}, \mathrm{Mg}^{2+}$ and $\mathrm{Fe}^{2+}$ ions into the pore fluids, while $\mathrm{CO}_{2}$ may be derived from the maturation of kerogen and decarboxylation of organic matter from the adjacent mudstone or source rocks [44-46]. The dissolution of detrital anorthite and carbonate grains is not obvious in the Lulehe sandstone, and the distribution pattern and occurrence form of the carbonate cements (Figure 8) suggests that external or mixed sources may be the main sources for these cements, which is consistent with the estimation scatter diagram of the material source based on the $\delta^{13} \mathrm{C}_{\mathrm{PDB}}$ and $\delta^{18} \mathrm{O}_{\mathrm{PDB}}$ isotopic values (Figure12a). The integration of the $\delta^{13} \mathrm{C}$ and $\delta^{18} \mathrm{O}$ isotopic values of carbonate cements and the burial and thermal history can effectively elucidate the origin of the potential source material and precipitation temperature involved in the cementation process. Generally, the $\delta^{13} \mathrm{C}$ isotopic value distribution in carbonates is mainly related to carbon sources. For instance, in carbonates of the atmospheric source (meteoric water) are approximately $-7 \%$ o [47], whereas $\mathrm{CO}_{2}$ associated with organic matter tends to have more negative $\delta^{13} \mathrm{C}$ values of $-18 \%$ o to $-33 \%$ o because the organic matter is depleted in ${ }^{13} \mathrm{C}$ [48]. However, $\mathrm{CO}_{2}$ in the carbonates that precipitate under methanogenic conditions has higher $\delta^{13} \mathrm{C}_{\mathrm{PDB}}$ values, ranging from $-5 \%$ o to $+15 \%$ o [49]. The $\delta^{13} \mathrm{C}_{\mathrm{PDB}}$ values of the carbonate cements in the Lulehe sandstones vary from $-15.21 \%$ o to $-3.21 \%$ o, suggesting a mixed source origin [49]. As a consequence of the calcite (Ca-I) have presumably formed near the sediment-water interface, and there two points where the $\delta^{13} \mathrm{C}_{\mathrm{PDB}}$ values of the Ca-I are around $-7 \%$ o (Table 2 ), suggesting that the source of Ca-I may be affected by meteoric water to some extent. However, the Lulehe Formation being progressively buried and not suffering from erosion during uplift to the surface in the burial history (Figure 3), it can be concluded that meteoric water exerted a negligible influence on the source of carbonate cement (Ca-II, ferroan calcite and ankerite) which occurred in deep buried depth [49]. In addition, the ternary diagram of the relative $\mathrm{Fe}-\mathrm{Mn}-\mathrm{Mg}$ contents of diagenetic calcites shows that most of the points are close to the distribution of the end members of Fe-Mg (Figure 12b), also suggesting that the formation of cement was controlled by pore water and fluid formed during organic diagenesis $[50,51]$, while the influence of meteoric water was relatively insignificant. Thus, the growth of carbonate cements might be derived from bioclast- and organic-derived $\mathrm{CO}_{2}$ during burial (Figure 12a).

The $\delta^{18} \mathrm{O}$ isotopic values of carbonate cements could reflect the precipitation temperature and composition of the diagenetic fluid [52]. The $\delta^{18} \mathrm{O}$ isotopic values of meteoric water have a large range from $-50 \%$ to $0 \%$ o (SMOW, standard mean ocean water), while the $\delta^{18} \mathrm{O}_{\mathrm{SMOW}}$ values of ocean water are approximately $0 \%$, where as pore fluids in the reservoir usually deviate towards higher $\delta^{18} \mathrm{O}$ isotope values due to water-rock interactions [52]. The precipitation temperatures for carbonate cements can be calculated in terms of the equation by Craig [53]:

$$
\mathrm{T}\left({ }^{\circ} \mathrm{C}\right)=16.9-4.2\left(\delta^{18} \mathrm{O}_{\mathrm{PDB}}-\delta^{18} \mathrm{O}_{\mathrm{SMOW}}\right)+0.13\left(\delta^{18} \mathrm{O}_{\mathrm{PDB}}-\delta^{18} \mathrm{O}_{\mathrm{SMOW}}\right)^{2}
$$

$\delta^{18} \mathrm{O}_{\mathrm{PDB}}$ represents the oxygen isotope value of carbonate cements, \%o PDB, and $\delta^{18} \mathrm{O}_{\mathrm{SMOW}}$ means the oxygen isotopic value of pore fluid in equilibrium with calcite and dolomite, \%o SMOW. However, there is no direct research on the $\delta^{18} \mathrm{O}_{\text {SMOW }}$ of pore fluids in the Lulehe Formation. Previous studies on the linear relationship between $\delta \mathrm{D}$ and $\delta^{18} \mathrm{O}_{\text {SMOW }}$ defined the relationship as a global meteoric 
water line, and the relationship between $\delta^{18} \mathrm{O}_{\mathrm{SMOW}}$ and $\delta \mathrm{D}$ in China was established based on $30 \mathrm{GINP}$ (Global Network of Isotopes in Precipitation) monitoring results [54]:

$$
\delta \mathrm{D}=7.57 \times \delta^{18} \mathrm{O}_{\mathrm{SMOW}}+6.02
$$

Since the calculated precipitation temperature of carbonate cement is based on the estimation of a global meteoric water line, it may have an error of approximately $10^{\circ} \mathrm{C}$. The average $\delta \mathrm{D}$ of the Qaidam Basin is $-21 \%$ o [55]; thus, the $\delta^{18} \mathrm{O}_{\text {SMOW }}$ value is $-3.6 \%$ occording to the calculation of the equation. With the pore fluid $\delta^{18} \mathrm{O}_{\mathrm{SMOW}}$ value and the carbonate cement precipitation temperatures, $57.62{ }^{\circ} \mathrm{C}$ to $75.08^{\circ} \mathrm{C}$ (Table 2), which corresponds to the late phase of early diagenesis.

Differences in the carbon isotopic composition and the calculated precipitation temperatures among calcite, dolomite, ferroan-calcite, and ankerite imply that they may have different precipitation mechanisms. The $\delta^{13} \mathrm{C}_{\mathrm{PDB}}$ of $\mathrm{Ca}-\mathrm{II}$, ferroan-calcite and ankerite are relative light, ranging from $-15.21 \%$ o to $-6.58 \%$, and the calculated precipitation temperature of the Ca-II, ferroan-calcite and ankerite with an average value of $109.24^{\circ} \mathrm{C}, 99.82^{\circ} \mathrm{C}, 113.57^{\circ} \mathrm{C}$, respectively, indicating that the increasing input of organic acids and $\mathrm{CO}_{2}$ may be induced by decarboxylation of organic matter at high temperatures. Changes in $\mathrm{Mn}^{2+}$ in carbonate cement are most likely related to alteration of volcanic materials (Table 1); moreover, alteration of the unstable volcanic rock fragments and illitization of smectite and kaolinite at the right temperatures also produce abundant $\mathrm{Mg}^{2+}$ and $\mathrm{Fe}^{2+}$ cations $[37,40]$. When the other cations in carbonates are gradually replaced by $\mathrm{Fe}^{2+}$ and $\mathrm{Mg}^{2+}$, ferroan-calcite and ankerite are formed.

\subsection{Origin and Sources of Quartz and Clays}

\subsubsection{Source of Quartz Cements}

Quartz cement may have multiple sources, including dissolution of biogenic amorphous silica and volcanic rock fragments, alteration of clay minerals, dissolved feldspar grains, and pressure solution of quartz grains, and all of them have internal and external sources [56,57]. However, unlike the solubility of $\mathrm{Ca}^{2+}$ and $\mathrm{Mg}^{2+}$ ions, that of $\mathrm{SiO}_{2}$ (aq.) and $\mathrm{Al}^{3+}$ is extremely low in deeply buried geological systems, and together with constraints of heterogeneity in reservoir quality and fluid volume and without certain driving forces, massive transport of external $\mathrm{SiO}_{2}$ (aq.) over long distances into sandstones is almost impossible $[18,58]$. Thus, with unrealistic external sources, the most likely silica sources for quartz cement were derived from internal sources.

Observations of thin sections reveal that there is no occurrence of abundant biogenic silica materials, so amorphous silica seems unlikely as a potential source for the quartz cements in the Lulehe sandstones. However, feldspar minerals are rich in Lulehe sandstones and petrographic evidence reveals that dissolution of feldspar is commonly accompanied by kaolinite and quartz cement (Figure 8f), which suggests the dissolution of feldspar is likely an important candidate source for quartz cements. Meanwhile, the maximum concentration of short chain carboxylic acid produced by organic maturation is between $75^{\circ} \mathrm{C}$ and $90^{\circ} \mathrm{C}$, and the optimum temperature for the preservation of organic acids is $80-120^{\circ} \mathrm{C}$ [59]. This temperature regime increased the rate of reaction of dissolution of feldspar grains [15]; thus, the growth of quartz cements due to an influx of $\mathrm{SiO}_{2}$ has been associated with the concomitant alteration of feldspar to silica and kaolinite by feldspar-clay reactions due to acid buffering. In addition, fluid inclusion homogenization temperatures for quartz cements range from $70{ }^{\circ} \mathrm{C}$ to $120^{\circ} \mathrm{C}$ (Figure 13c), which is consistent with optimum temperatures for the preservation of organic acids, also providing potential evidence for silica sources for quartz cements partly originating from feldspar dissolution.

Volcanic rock fragments are also common in the Lulehe sandstones, and they can be prone to transformation into smectite during eodiagenesis [60]; with progressive burial and increasing temperature, unstable smectite and kaolinite will transform to illite at temperatures of approximately $70{ }^{\circ} \mathrm{C}$ and $120^{\circ} \mathrm{C}$, respectively [61], and then $\mathrm{SiO}_{2}$ will be released into the pore fluid. The XRD analysis statistical data reveal that illite comprises the most abundant content, ranging from $17 \%$ to $85 \%$ (avg. 
$6.8 \%$ ), of the total clay minerals in the Lulehe sandstones, while smectite and kaolinite comprise only approximately $1.5 \%$ and $2 \%$ on average, respectively. This finding suggests that illitization of smectite and kaolinite is a possible source for quartz cements. In addition, the appearance of concavo-convex and sutured contact types suggesting the acquisition of silica through pressure dissolution can be another internal source for quartz cements.

\subsubsection{Source of Clay Minerals}

Authigenic clay minerals (e.g., chlorite, kaolinite, illite-smectite and illite) are ubiquitous types of cement in the Lulehe sandstones. Several previous studies have proposed that the origin of chlorite is generally associated with precursor clay mineral and high Fe and $\mathrm{Mg}$ ion content environments [61,62]. Chlorite forms in a variety of precursor clay minerals, but the main precursors include berthierine and smectite [63]. Berthierine is a Fe-rich clay mineral precursor developed from the interaction of the Al-Fe minerals with pore fluids under reducing conditions at the time of deposition [60]. Smectite reacts with iron oxide and saline pore waters to form chlorite, which can be prone to derived from alteration of volcanic rock fragments during the eodiagenesis stages [64]. Since berthierine is rarely detected and volcanic rock fragments are widely developed in the Lulehe sandstone, smectite, which is commonly derived from alteration of volcanic rock fragments, may be the primary clay mineral precursor of chlorite. In addition, the Lulehe sandstones were mainly deposited in fluvial deltaic environments, and proximal and distal delta fronts are particularly rich in Fe [65]. Moreover, the dissolution of volcanic rock fragments and feldspar grains also provides rich $\mathrm{Fe}$ and $\mathrm{Mg}$ ions as the main source for chlorite development.

Authigenic kaolinite is closely associated with feldspar dissolution (Figure 11h), which suggests that alteration of detrital feldspar grains is the most probable source for authigenic kaolinite [18,39]. Decomposed feldspar grains and the formation of authigenic kaolinite require a low $\mathrm{K}^{+} / \mathrm{H}^{+}$activity ratio, and acidic (low $\mathrm{K}^{+} / \mathrm{H}^{+}$) pore fluids are presumably related to the decarboxylation of organic matter from the adjacent mudstone or source rocks [58]. However, the solubility of $\mathrm{Al}^{3+}$ ions derived from dissolved feldspar is extremely low [18,58]; as a result, kaolinite is likely precipitated in situ or in adjacent pores and is spatially synchronous with feldspar dissolution. With the increase in temperature and consumption of organic acids, the ratio of $\mathrm{K}^{+} / \mathrm{H}^{+}$increases; consequently, the stability field of kaolinite is greatly reduced and can be easily converted to mixed layer illite/smectite and illite [6]. In addition, XRD data of clay minerals in the Lulehe sandstone show that illite dominates in sandstones with depth deeper than $3300 \mathrm{~m}$ (Figure 9a), whereas the content of kaolinite increased significantly above $3330 \mathrm{~m}$ (Figure 10b), also suggesting that kaolinite may be one of the material sources of illite. The mixing layer of illite and smectite increased with the depth (Figure 10c), while the content of smectite in the mixing layer of illite and smectite decreased with the depth (Figure 10d), indicating that some smectite may be transformed into illite.

\subsection{Diagenetic Sequence}

The diagenetic evolution regime generally includes eodiagenesis and mesodiagenesis stages sensu Morad et al. [66]. Eodiagenesis occurs mainly in an environment where the burial depth $<2.7 \mathrm{~km}$ and the temperature $<70{ }^{\circ} \mathrm{C}$ in the Lulehe sandstone reservoir, and the interstitial fluid chemistry is affected by depositional environment, whereas mesodiagenesis commonly occurs at $>2.7 \mathrm{~km}$ of burial depth and temperatures $>70^{\circ} \mathrm{C}$ (Figure 3), which is mediated by evolved diagenetically altered fluids [67]. Although it is difficult to determine the precise timing and burial depth of diagenetic alterations [61], a general paragenetic sequence can be reconstructed and established by synthesizing the petrologic features, burial and thermal histories, various diagenetic minerals and relationships of mineral texture, clay mineral reactions associated with origin and source, and relative timing of the major diagenetic events of the Lulehe sandstones, as shown in Figure 14.

The sediments were subjected to mechanical compaction once deposited, as characterized by framework grain rearrangement and deformation of ductile grains (Figure $7 \mathrm{a}-\mathrm{c}$ ). In addition, Calcite 
(Ca-I) have presumably formed near the sediment-water interface during early diagenesis (shallow burial realm), as evidenced by poikilotopic, pore-filling blocky, and aggregate pore-filling forms, it can be interpreted to have formed in the early stage of diagenesis (shallow burial realm) before significant compactional porosity-loss could occur. As the sediment is exposed to mechanical penetration near the surface, grains coated with clays (Figure 7a,b) may have developed in shallow depth. Authigenic chloritetypically develops at temperatures of $>60$ or $70{ }^{\circ} \mathrm{C}$ [12], corresponding to a depth of about 2400-2800 m (Figure 3) and belongs to eodiageneticstages. During the early diagenetic stage, volcanic rock fragments can be easily transformed into smectite, as burial depth and temperature increase, illitization of smectite will occurat a temperature around $70{ }^{\circ} \mathrm{C}$ [13], corresponds to a depth of about $2700 \mathrm{~m}$ in study area (Figure 3). In addition, the onset of authigenic quartz was interpreted at about $70-80{ }^{\circ} \mathrm{C}$ [45], corresponding to the burial depth from 2700 3200 $\mathrm{m}$ (Figure 3). Moreover, the $\delta^{13} \mathrm{C}$ and $\delta^{18} \mathrm{O}$ isotopic data of the carbonate cements and the homogenization temperatures (Th) of the aqueous inclusions in the diagenetic minerals may help to decipher the origin and source as well as the timing of precipitation of the minerals, integrated with the distribution pattern of the diagenetic minerals. It can be inferred that the significant eodiagenesis regime features mainly include (1) mechanical compaction, (2) precipitation of Ca-I and dolomite, (3) alteration of volcanic rock fragments and smectite development, (4) development of grain-coating chlorite, (5) precipitation of authigenic quartz, and (6) a minor amount of smectite transformed into illite.

As burial depth and temperature progressively increase during mesodiagenesis, porosity is destroyed predominantly by chemical compaction. Organic matter gradually becomes thermally mature, which generates organic acid and $\mathrm{CO}_{2}$ above the critical onset temperature of $75^{\circ} \mathrm{C}$ commonly occurs at $>2.7 \mathrm{~km}$ of burial depth in Lulehe sandstone reservoir (Figure 3), and the optimum temperature for the preservation of organic acids is $80-120^{\circ} \mathrm{C}$ [18], corresponding to the burial depth from 3200 4000 $\mathrm{m}$ (Figure 3). The $\mathrm{pH}$ values of the formation water decrease thereby dissolving early stage carbonate cements (Ca-I) and feldspar by low pH fluids, contributing to secondary porosity development. However, dissolution of feldspar releases aluminum and aqueous silica, which have low mobility and are considered to migrate over short distances, resulting in authigenic kaolinite and quartz cement precipitation in situ or in adjacent pores [58], indicate that kaolinite is closely associated with alteration of feldspar grains in the low $\mathrm{pH}$ (acidic) fluid which plausibly have been generated at depth burial depth from 3200 4000 m. Simultaneously, with the increase in $\mathrm{K}^{+}$released by feldspar dissolution, under high temperatures, the hair-like, spiny terminations and honeycomb-like habits of illite occur. During the late stage of mesodiagenesis, due to the consumption of organic acids and $\mathrm{CO}_{2}$ during aluminosilicate dissolution, the $\mathrm{pH}$ value of the formation water increased, which is favorable for the precipitation of late carbonate cement (Ca-II, ferroan calcite and ankerite) (Figure 14). As a result, the mesogenetic process (deep burial realm) mainly includes: (1) chemical compaction, (2) dissolution of feldspar grains, (3) precipitation of kaolinite, (4) quartz overgrowth, (5) illitization of kaolinite, (6) development of pore-filling chlorite, and (7) precipitation of Ca-II, ferroan calcite and ankerite. 


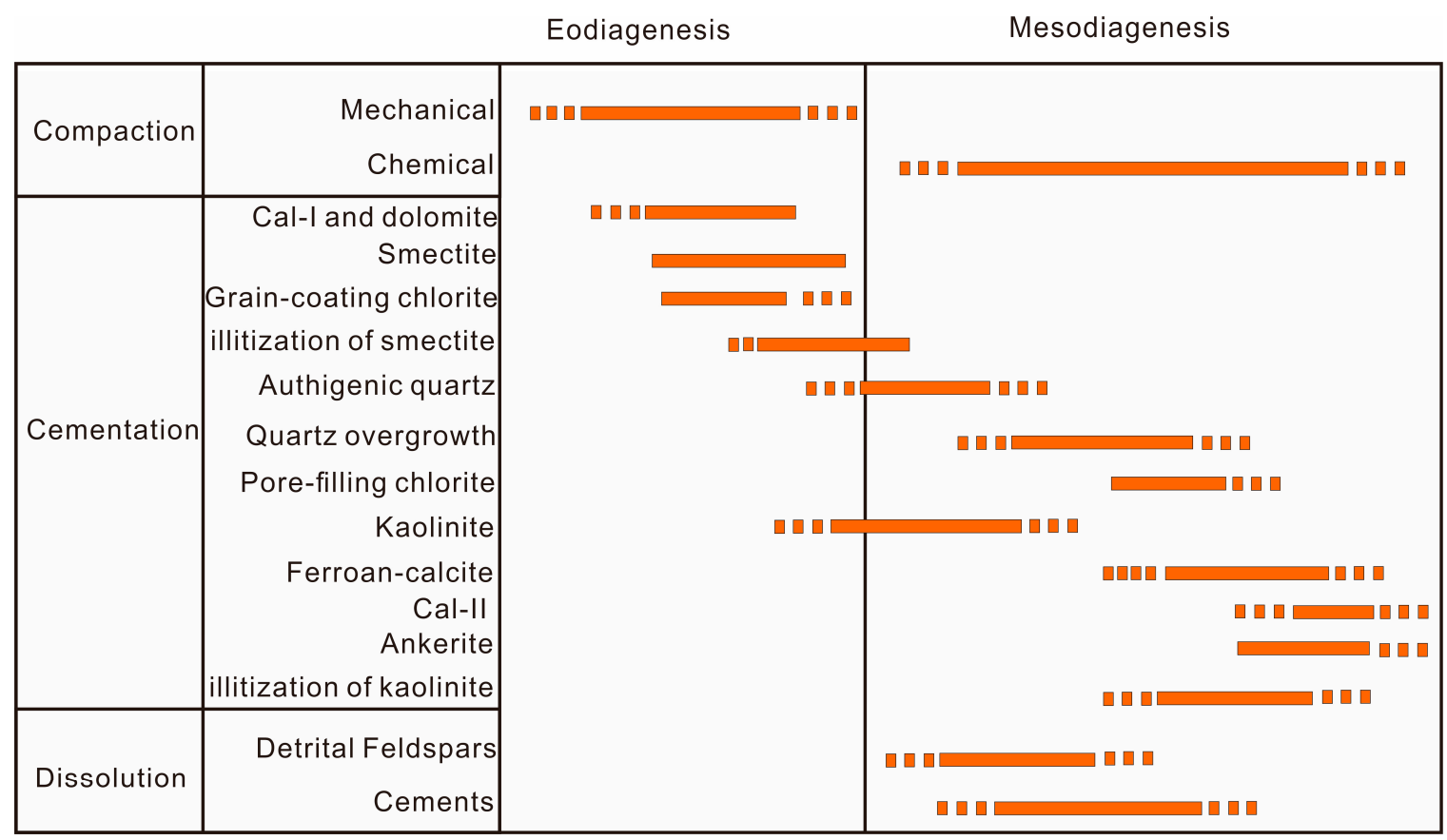

Figure 14. Paragenetic sequences of the Lulehe sandstone.

\subsection{Impacts of Diagenesis on Reservoir Quality}

Reservoir quality of the Lulehe Formation has been significantly controlled by various types of diagenetic alteration. The main diagenetic processes that controlled reservoir quality were compaction, precipitation of carbonate cements, formation of chlorite, quartz cements, development of illite, and dissolution of unstable grains and cements.

Compaction is the principal factor responsible for the deterioration of reservoir quality, followed by cementation, which is confirmed by using the methodology of Houseknecht [68] and Ehrenberg [69], as shown in Figure 15a. Porosity loss is due to rapid and progressive burial (Figure 3), and the petrographic analysis data revealed that mechanical compaction diminished porosity, as indicated by the presence of grain rotation, bending of micas, and deformation of mud intraclasts and ductile grains forming a pseudomatrix. The grain contacts gradually change from floating to point and line contact, indicating that mechanical compaction occurred progressively during shallow depth burial realm (eodiageneticstages). The primary intergranular porosity decreased by the recombination of grains. In addition, the appearance of concavo-convex and sutured contact types suggests that chemical compaction occur in deep burial realm (mesodiagenetic stages), is a possible silica source for quartz overgrowth, which may further occupy the pore space and harm the reservoir quality.

Carbonate minerals are the most common cements in the Lulehe sandstones, indicating that carbonate cement (e.g., calcite, dolomite, ferroan calcite and ankerite) also played a major role in drastically reducing reservoir quality. The sum of total calcite and dolomite along with ferroan calcite and ankerite cements exhibits a relatively good inverse correlation with porosity and permeability (Figure 16a,b), suggesting that reservoir quality was reduced by carbonate cement. The carbonate cement formed in the eodiagenetic stage (Ca-I) of shallow buried depth, due to its shallow burial, the particles have not been completely consolidated by the compaction stress. As a result, Ca-I exert a certain supporting effect on the particle skeleton against compaction, so it can enhance the compressive ability to some extent. The carbonate cements (Ca-II) including ferrocalcite and ankerite which were mainly formed in the mesodiagenetic stages, with the burial depth increasing, the reservoir has experienced strong compaction, and its supporting effect on the rock skeleton can be ignored. On the contrary, the late carbonate cements will occupy part of the dissolved pore, which resulted in the possibility of forming intergranular and intragranular pores are reduced. 

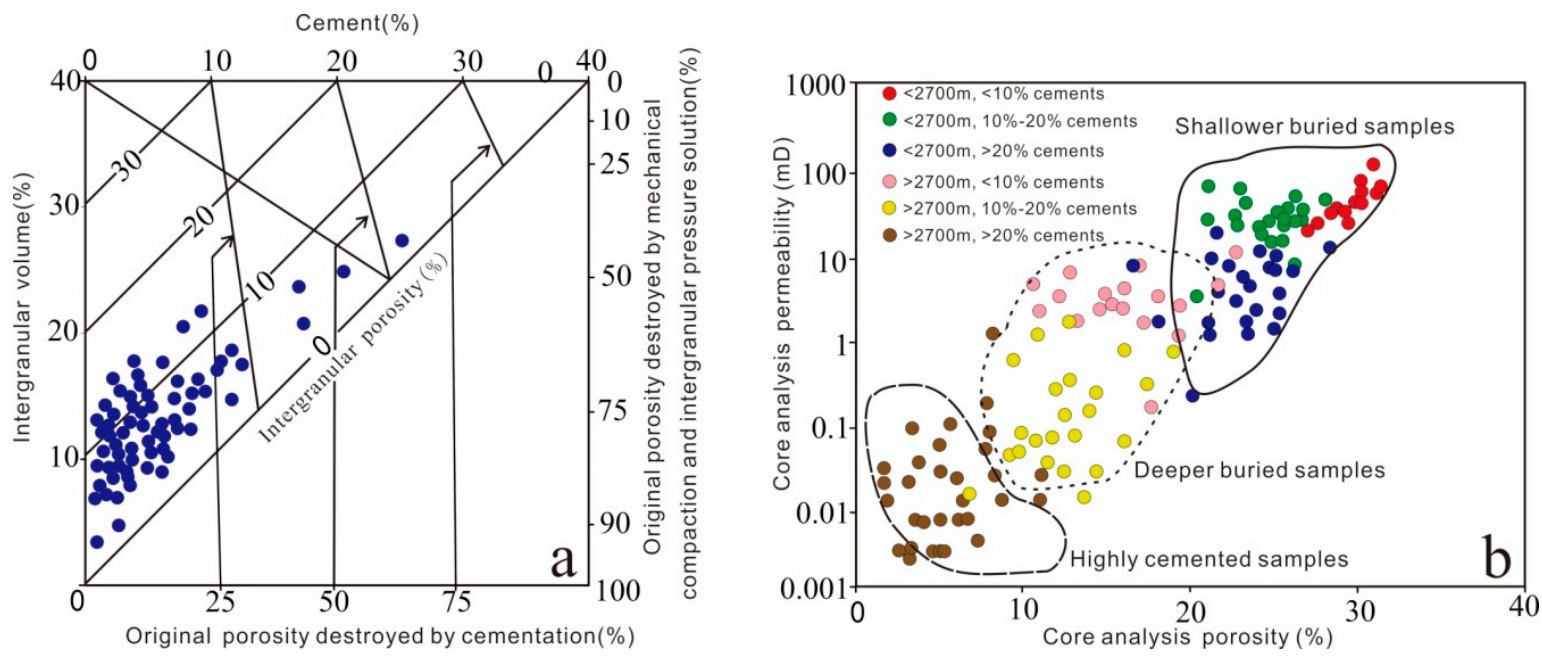

Figure 15. (a) Plot of intergranular volume (IGV) versus volume of cement, diagram after Houseknecht [68] and Ehrenberg [69]. (b) Core porosity versus core permeability of the Lulehe sandstones with different depth and cements content.
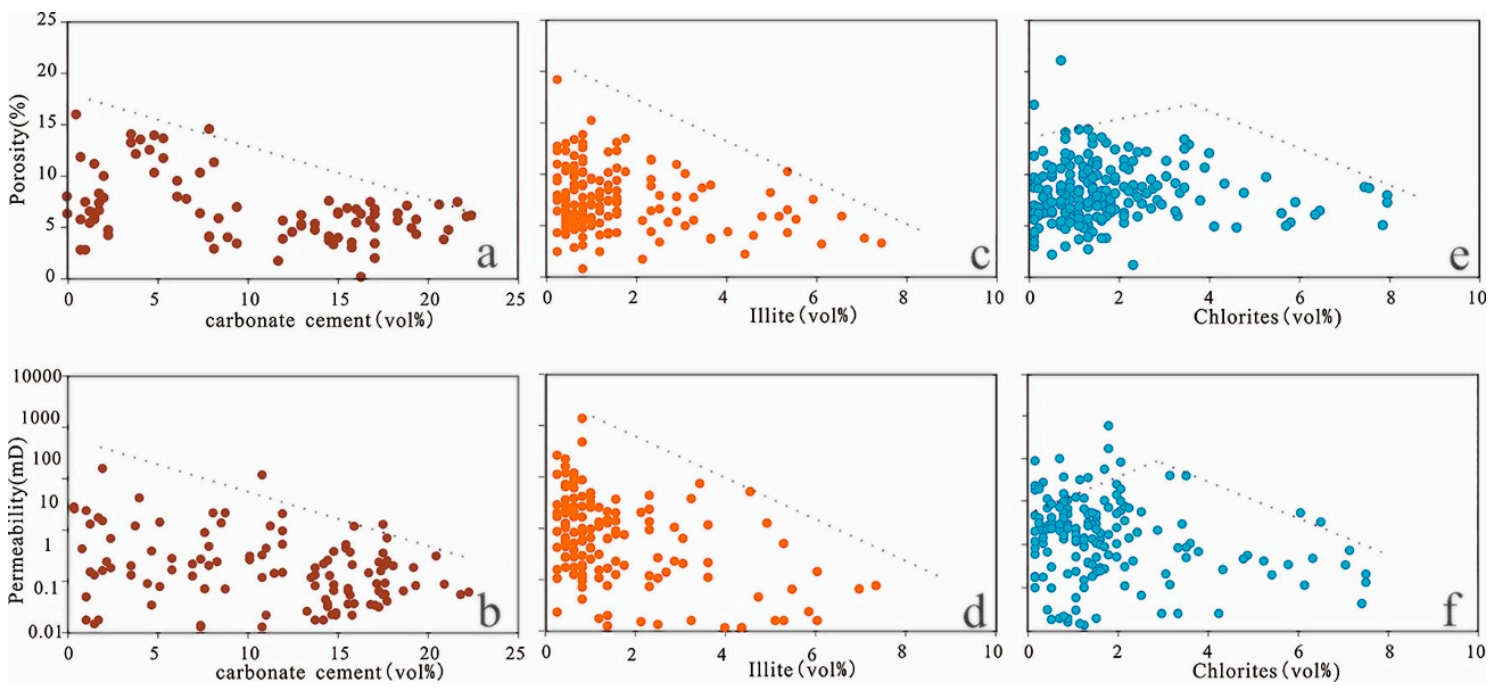

Figure 16. (a) Porosity versus carbonate cements. (b) Permeability versus carbonate cements. (c) Porosity versus illite cements. (d) Permeability versus illite cements. (e) Porosity versus chlorite cements. (f) Permeability versus chlorite cements.

Authigenic clays present in the Lulehe Formation consist mostly of chlorite, kaolinite and illite. As a byproduct of feldspar dissolution, kaolinite usually develops intercrystalline microporosity, which does not possess a significant influence on reservoir properties. Under high temperatures and deep burial depths, illitization of kaolinite and precipitation of quartz cement occur after feldspar dissolution. The presence of quartz cements mostly occurs as syntaxial overgrowths around detrital quartz grains and illite typically appear as fibrous aggregates that bridge and fill in primary pores and secondary pores. Thus, illite and quartz cement reduce reservoir quality by occluding pore spaces and decreasing pore radii (Figure 16c,d). However, grain-coating chlorites have been widely accepted as important mechanisms for reservoir quality preservation because chlorite rims delay or inhibit the precipitation of quartz overgrowth during burial [70-72]. Within the study area, porosity increases with chlorite content up to approximately $3 \%$ volume and then decreases slightly (Figure 16e,f); thus, chlorite coatings are beneficial at an optimum volume of $3 \%$. In other words, if chlorite coatings are too thick, they will occur as pore-filling cements and become important causes of porosity loss. 
Through dissolution, ductile fragments and calcite cements often formed irregular intergranular and intragranular pores (Figure 6d). In addition, feldspar grains commonly dissolved in Lulehe sandstone reservoir, and as a result, embayment-shaped intergranular pores were observed (Figure 9c). Furthermore, a small number of honeycomb intergranular pores resulted from severe feldspar dissolution, which was always accompanied by silica and kaolinite precipitation (Figure 9f, Figure 11h). A benefit of dissolution of unstable minerals (e.g., ductile fragments and carbonate cements) and feldspar grains is the occurrence of secondary porosity, which may enhance porosity to some extent. However, the deep burial environment seems to be a closed system, and the solutes cannot be transported over a large scale $[6,58]$. As a result, simultaneous precipitation of byproducts of feldspar dissolution such as authigenic kaolinite and quartz cement will occur in situ or in adjacent pores [58]. Consequently, the net porosities created by dissolution of unstable minerals and feldspar grains may be insignificant. Moreover, reprecipitated cement material occupies the pore space and diminishes pore throat connectivity, resulting in reduced permeability and increasing reservoir heterogeneity.

In addition, the porosity and permeability of the reservoir are directly related to the burial depth and cement content as show in Figure 15b. The shallowest buried depth corresponds to the lowest compaction effective stress, so the corresponding samples have the highest porosity and permeability. Also, the sandstones with the higher cement contents tend to have lower permeability for a given porosity than those with lower cement contents. The difference of cement content and buried depth plays an important role in sandstone reservoirs in the study area.

\section{Conclusions}

1. The Lulehe Formation sandstones are very fine-grained, moderate to well sorted, feldspathic litharenites and lithic arkose mainly deposited in alluvial fan and fluvial deltaic environments. The sandstones have considerable heterogeneity with a wide range of porosity from $1.69 \%$ to $31.33 \%$, with an average of $9.65 \%$, and permeability from 0.03 to $366.52 \mathrm{mD}$, with an average of $13.75 \mathrm{mD}$.

2. The diagenetic regimes range from eodiagenesis to mesodiagenesis. Eodiagenesis includes mechanical compaction, precipitation of calcite and dolomite, alteration of volcanic rock fragments and smectite development, development of grain-coating chlorite, and a minor amount of smectite transformed into illite. Mesodiagenesis includes chemical compaction, development of pore-filling chlorite, formation of late carbonate cement and illite, quartz overgrowths, and dissolution of metastable cements and feldspar grains.

3. Carbonate cements might originate from mixed sources of bioclast- and organic-derived $\mathrm{CO}_{2}$ during burial. Quartz cement is probably the result of feldspar dissolution, alteration of volcanic rock fragments, transformation of smectite into illite, and pressure solution of quartz grains. Smectite commonly derived from alteration of volcanic rock fragments may be the primary clay mineral precursor of chlorite. In addition, the dissolution of volcanic rock fragments and feldspar grains also provides abundant $\mathrm{Fe}^{2+}$ and $\mathrm{Mg}^{2+}$ as a potential source for chlorite development. Authigenic kaolinite is closely associated with feldspar dissolution, suggesting that alteration of detrital feldspar grains is the most probable source for authigenic kaolinite. With the increase in temperature and consumption of organic acids, the ratio of $\mathrm{K}^{+} / \mathrm{H}^{+}$increases and the stability field of kaolinite is greatly reduced, thereby transforming kaolinite into mixed layer illite/smectite and illite.

4. Compaction is the principal factor for the deterioration of reservoir quality. In addition, carbonate cement, quartz overgrowth and the formation of mixed illite-smectite and illite are the subsequent main factors for porosity reduction, whereas grain-coating chlorites are mainly mechanisms for preservation of the reservoir quality, but immoderately thick chlorite coatings will also obstruct the pore throats and result in reservoir quality reduction.

5. Dissolution of metastable minerals and grains may lead to the occurrence of secondary porosity and enhance porosity to some extent. However, the solute cannot be transported over a large scale in the deep burial environment; as a consequence, simultaneous precipitation of byproducts of feldspar 
dissolution, such as authigenic kaolinite and quartz cement, will occur in situ or in adjacent pores, which results in further heterogeneity of the reservoirs.

Author Contributions: Conceptualization, B.C. and F.W.; Methodology, B.C.; Validation, B.C. and H.S; Investigation, J.S; Resources, F.C.; Project Administration, J.S. and H.S.

Funding: This research was funded by the High level innovation teams and excellent scholars program in Guangxi Universities (Guijiao Ren [2016]42), the Basic Ability Improvement Project for Young and Middle-aged Teachers in Guangxi (2018KY0610) and Scientific research project of Beibu Gulf University (17KYQD57).

Acknowledgments: We thank the Qinghai Oilfield Company of petroChina for providing all related research core samples and some of the geological data.

Conflicts of Interest: The authors declare no conflict of interest.

\section{References}

1. Ajdukiewicz, J.M.; Lander, R.H. Sandstone reservoir quality prediction: The state of the art. Am. Assoc. Pet. Geol. Bull. 2010, 94, 1083-1091. [CrossRef]

2. Taylor, T.R.; Kittridge, M.G.; Winefield, P.; Bryndzia, L.T.; Bonnell, L.M. Reservoir quality and rock properties modeling-Triassic and Jurassic sandstones, greater Shearwater area, UK Central North Sea. Mar. Pet. Geol. 2015, 65, 1-21. [CrossRef]

3. Zhang, W.; Jian, X.; Fu, L.; Feng, F.; Guan, P. Reservoir characterization and hydrocarbon accumulation in late Cenozoic lacustrine mixed carbonate-siliciclastic fine-grained deposits of the northwestern Qaidam basin, NW China. Mar. Pet. Geol. 2018, 98, 675-686. [CrossRef]

4. Busch, B.; Hilgers, C.; Lander, R.H.; Bonnell, L.M.; Adelmann, D. Reservoir quality and burial model evaluation by kinetic quartz and illite cementation modeling: Case study of Rotliegendes, north Germany. Am. Assoc. Pet. Geol. Bull. 2018, 102, 293-307. [CrossRef]

5. Morad, S.; Ketzer, J.M.; De Ros, L.F. Linking Diagenesis to Sequence Stratigraphy: An Integrated Tool for Understanding and Predicting Reservoir Quality Distribution. Link Diagenes Seq. Stratigr. 2013, 45, 1-36. [CrossRef]

6. Bjørlykke, K. Relationships between depositional environments, burial history and rock properties. Some principal aspects of diagenetic process in sedimentary basins. Sediment. Geol. 2014, 301, 1-14. [CrossRef]

7. Taylor, T.R.; Giles, M.R.; Hathon, L.A.; Diggs, T.N.; Braunsdorf, N.R.; Birbiglia, G.V.; Kittridge, M.G.; Macaulay, C.I.; Espejo, I.S. Sandstone diagenesis and reservoir quality prediction: Models, myths, and reality. Am. Assoc. Pet. Geol. Bull. 2010, 94, 1093-1132. [CrossRef]

8. Leila, M.; Moscariello, A.; Šegvić, B. Depositional facies controls on the diagenesis and reservoir quality of the MessinianQawasim and Abu Madi formations, onshore Nile Delta, Egypt. Geol. J. 2019, 54, 1797-1813. [CrossRef]

9. Amel, H.; Jafarian, A.; Husinec, A.; Koeshidayatullah, A.; Swennen, R. Microfacies, depositional environment and diagenetic evolution controls on the reservoir quality of the Permian Upper Dalan Formation, Kish Gas Field, Zagros Basin. Mar. Pet. Geol. 2015, 67, 57-71. [CrossRef]

10. Lima, R.D.; De Ros, L.F. The role of depositional setting and diagenesis on the reservoir quality of Devonian sandstones from the Solimões Basin, Brazilian Amazonia. Mar. Pet. Geol. 2002, 19, 1047-1071. [CrossRef]

11. Henares, S.; Caracciolo, L.; Viseras, C.; Fernández, J.; Yeste, L.M. Diagenetic constraints on heterogeneous reservoir quality assessment: A Triassic outcrop analog of meandering fluvial reservoirs. Am. Assoc. Pet. Geol. Bull. 2016, 100, 1377-1398. [CrossRef]

12. Morad, S.; Al-Aasm, I.S.; Nader, F.H.; Ceriani, A.; Gasparrini, M.; Mansurbeg, H. Impact of diagenesis on the spatial and temporal distribution of reservoir quality in the Jurassic Arab D and C members, offshore Abu Dhabi oilfield, United Arab Emirates. GeoArabia 2012, 17, 17-56.

13. Oluwadebi, A.G.; Taylor, K.G.; Dowey, P.J. Diagenetic controls on the reservoir quality of the tight gas Collyhurst Sandstone Formation, Lower Permian, East Irish Sea Basin, United Kingdom. Sediment. Geol. 2018, 371, 55-74. [CrossRef]

14. Gutiérrez Paredes, H.C.; Catuneanu, O.; Hernández Romano, U. Controls on the quality of Miocene reservoirs, southern Gulf of Mexico. J. South Am. Earth Sci. 2018, 81, 45-65. [CrossRef] 
15. Mansurbeg, H.; Morad, S.; Salem, A.; Marfil, R.; El-Ghali, M.A.; Nystuen, J.P.; Caja, M.A.; Amorosi, A.; Garcia, D.; La Iglesia, A. Diagenesis and reservoir quality evolution of palaeocene deep-water, marine sandstones, the Shetland-Faroes Basin, British continental shelf. Mar. Pet. Geol. 2008, 25, 514-543. [CrossRef]

16. Karmakar, R.; Manna, S.S.; Dutta, T. A geometrical model of diagenesis using percolation theory. Phys. A Stat. Mech. Appl. 2003, 318, 113-120. [CrossRef]

17. Hakimi, M.H.; Shalaby, M.R.; Abdullah, W.H. Diagenetic characteristics and reservoir quality of the Lower Cretaceous Biyadh sandstones at Kharir oilfield in the western central Masila Basin, Yemen. J. Asian Earth Sci. 2012, 51, 109-120. [CrossRef]

18. Bjørlykke, K. Open-system chemical behaviour of Wilcox Group mudstones. How is large scale mass transfer at great burial depth in sedimentary basins possible? A discussion. Mar. Pet. Geol. 2011, 28, 1381-1382. [CrossRef]

19. Thyne, G. A model of diagenetic mass transfer between adjacent sandstone and shale. Mar. Pet. Geol. 2001, 18, 743-755. [CrossRef]

20. Yuan, G.; Gluyas, J.; Cao, Y.; Oxtoby, N.H.; Jia, Z.; Wang, Y.; Xi, K.; Li, X. Diagenesis and reservoir quality evolution of the Eocene sandstones in the northern Dongying Sag, Bohai Bay Basin, East China. Mar. Pet. Geol. 2015, 62, 77-89. [CrossRef]

21. Zhang, Y.L.; Bao, Z.D.; Zhao, Y.; Jiang, L.; Zhou, Y.Q.; Gong, F.H. Origins of authigenic minerals and their impacts on reservoir quality of tight sandstones: Upper Triassic Chang-7 Member, Yanchang Formation, Ordos Basin, China. Aust. J. Earth Sci. 2017, 64, 519-536. [CrossRef]

22. Furong, W.; Sheng, H.; Yuguang, H.; Tian, D.; Zhiliang, H. The distribution and origin of carbonate cements in deep-buried sandstones in the central Junggar Basin, northwest China. Geofluids 2017, 2017, 18-23. [CrossRef]

23. Liu, M.; Shabaninejad, M.; Mostaghimi, P. Predictions of permeability, surface area and average dissolution rate during reactive transport in multi-mineral rocks. J. Pet. Sci. Eng. 2018, 170, 130-138. [CrossRef]

24. Poursoltani, M.R.; Gibling, M.R.; Pe-Piper, G. Diagenesis, burial history, and hydrocarbon potential of Cambrian sandstone in the northern continental margin of Gondwana: A case study of the Lalun Formation of central Iran. J. Asian Earth Sci. 2019, 172, 143-169. [CrossRef]

25. Christopher, B.A.; Kuiwu, L.; Oswald, G.W. Diagenesis and Reservoir Properties of the Permian Ecca Group Sandstones and Mudrocks in the Eastern Cape Province, South Africa. Minerals 2017, 7, 88. [CrossRef]

26. Feng, J.; Cao, J.; Hu, K.; Peng, X.; Chen, Y.; Wang, Y.; Wang, M. Dissolution and its impacts on reservoir formation in moderately to deeply buried strata of mixed siliciclastic-carbonate sediments, northwestern Qaidam Basin, northwest China. Mar. Pet. Geol. 2013, 39, 124-137. [CrossRef]

27. Sun, G.; Yin, J.; Zhang, S.; Lu, X.; Zhang, S.; Shi, J. Diagenesis and sedimentary environment of Miocene series in Eboliang III area. Environ. Earth Sci. 2015, 74, 5169-5179. [CrossRef]

28. Junwu, L.; Chengjin, Y.; Fengjie, L.; Yongliang, W.; Tingyong, D. Provenance analysis of the Neogene in Eboliang area Qaidam Basin. J. Palaeogeogr. 2015, 17, 186-197. (In Chinese)

29. Hong, L.; Bing, Z. Neogene sedimentary facies in the Eboliang area of the northern Qaidam Basin. J. Stratigrap. 2016, 40, 57-62. (In Chinese)

30. Jian, X.; Guan, P.; Zhang, D.W.; Zhang, W.; Feng, F.; Liu, R.J.; Lin, S.D. Provenance of Tertiary sandstone in the northern Qaidam basin, northeastern Tibetan Plateau: Integration of framework petrography, heavy mineral analysis and mineral chemistry. Sediment. Geol. 2013, 290, 109-125. [CrossRef]

31. Wang, T.; Yang, S.; Duan, S.; Chen, H.; Liu, H.; Cao, J. Multi-stage primary and secondary hydrocarbon migration and accumulation in lacustrine Jurassic petroleum systems in the northern Qaidam Basin, NW China. Mar. Pet. Geol. 2015, 62, 90-101. [CrossRef]

32. Miao, W.L.; Fan, Q.S.; Wei, H.C.; Zhang, X.Y.; Ma, H.Z. Clay mineralogical and geochemical constraints on late Pleistocene weathering processes of the Qaidam Basin, northern Tibetan Plateau. J. Asian Earth Sci. 2016, 127, 267-280. [CrossRef]

33. Wang, Y.; Zheng, J.; Zhang, W.; Li, S.; Liu, X.; Yang, X.; Liu, Y. Cenozoic uplift of the Tibetan Plateau: Evidence from the tectonic-sedimentary evolution of the western Qaidam Basin. Geosci. Front. 2012, 3, 175-187. [CrossRef]

34. Zongxing, L.; Chenglin, L.; Yinsheng, M. Geothermal Field and Tectono-Thermal Evolution since the Late Paleozoic of the Qaidam Basin, Western China. Acta Geol. Sin. 2015, 89, 678. (In Chinese) [CrossRef] 
35. Zeqing, G.; Yinsheng, M.; Weihong, L.; Liqun, W.; Jixian, T.; Xu, Z.; Feng, M. Main factors controlling the formation of basement hydrocarbon reservoirs in the Qaidam Basin, western China. J. Pet. Sci. Eng. 2017, 149, 244-255. [CrossRef]

36. Folk, R.L. Petrology of Sedimentary Rocks; Hemphill Publishing Company: Austin, TX, USA, 1980; p. 182.

37. Rahman, M.J.J.; Worden, R.H. Diagenesis and its impact on the reservoir quality of Miocene sandstones (Surma Group) from the Bengal Basin, Bangladesh. Mar. Pet. Geol. 2016, 77, 898-915. [CrossRef]

38. Robinson, A.; Gluyas, J. Model calculations of loss of porosity in sandstones as a result of compaction and quartz cementation. Mar. Pet. Geol. 1992, 9, 319-323. [CrossRef]

39. Dutton, S.P. Calcite cement in Permian deep-water sandstones, Delaware Basin, west Texas: Origin, distribution, and effect on reservoir properties. Am. Assoc. Pet. Geol. Bull. 2008, 92, 765-787. [CrossRef]

40. Morad, S.; Al-Aasm, I.S.; Ramseyer, K.; Marfil, R.; Aldahan, A.A. Diagenesis of carbonate cements in Permo-Triassic sandstones from the Iberian Range, Spain: Evidence from chemical composition and stable isotopes. Sediment. Geol. 1990, 67, 281-295. [CrossRef]

41. Pszonka, J.; Wendorff, M. Carbonate cements and grains in submarine fan sandstones—the Cergowa Beds (Oligocene, Carpathians of Poland) recorded by cathodoluminescence. Int. J. Earth Sci. 2017, 106, 269-282. [CrossRef]

42. Guerra, N.C.; Kiang, C.H.; Sial, A.N. Carbonate cements in contemporaneous beachrocks, Jaguaribe beach, Itamaracáisland, northeastern Brazil: Petrographic, geochemical and isotopic aspects. An. Acad. Bras. Cienc. 2005, 77, 343-352. [CrossRef]

43. Sanyal, P.; Bhattacharya, S.K.; Prasad, M. Chemical diagenesis of Siwalik sandstone: Isotopic and mineralogical proxies from SuraiKhola section, Nepal. Sediment. Geol. 2005, 180, 57-74. [CrossRef]

44. Xiong, D.; Azmy, K.; Blamey, N.J.F. Diagenesis and origin of calcite cement in the Flemish Pass Basin sandstone reservoir (Upper Jurassic): Implications for porosity development. Mar. Pet. Geol. 2016, 70, 93-118. [CrossRef]

45. Yang, T.; Cao, Y.; Friis, H.; Liu, K.; Wang, Y.; Zhou, L.; Zhang, S.; Zhang, H. Genesis and distribution pattern of carbonate cements in lacustrine deep-water gravity-flow sandstone reservoirs in the third member of the Shahejie Formation in the Dongying Sag, Jiyang Depression, Eastern China. Mar. Pet. Geol. 2018, 92, 547-564. [CrossRef]

46. Odigi, M.I.; Amajor, L.C. Geochemistry of carbonate cements in Cretaceous sandstones, southeast Benue Trough, Nigeria: Implications for geochemical evolution of formation waters. J. African Earth Sci. 2010, 57, 213-226. [CrossRef]

47. Spotl, C.; Wrightt, V.P.; Institut, G. Groundwater dolocretes from the Upper Triassic of the Paris Basin, France: A case study of an arid, continental diageneticfacies. Sedimentology 1992, 39, 1119-1136. [CrossRef]

48. Drummond, C.N.; Wilkinson, B.H.; Lohmann, K.C.; Smith, G.R. Effect of regional topography and hydrology on the lacustrine isotopic record of Miocene paleoclimate in the Rocky Mountains. Palaeogeogr. Palaeoclimatol. Palaeoecol. 1993, 101, 67-79. [CrossRef]

49. Irwin, H.; Curtis, C.; Coleman, M. Isotopic evidence for source of diagenetic carbonates formed during burial of organic-rich sediments. Nature 1977, 269, 209-213. [CrossRef]

50. Travé, A.; Roca, E.; Playà, E.; Parcerisa, D.; Gómez-Gras, D.; Martín-Martín, J.D. Migration of Mn-rich fluids through normal faults and fine-grained terrigenous sediments during early development of the NeogeneVallès-Penedès half-graben (NE Spain). Geofluids 2009, 9, 303-320. [CrossRef]

51. Jin, Z.; Cao, J.; Hu, W.; Zhang, Y.; Yao, S.; Wang, X.; Zhang, Y.; Tang, Y.; Shi, X. Episodic petroleum fluid migration in fault zones of the northwestern Junggar Basin (northwest China): Evidence from hydrocarbon-bearing zoned calcite cement. Am. Assoc. Pet. Geol. Bull. 2008, 92, 1225-1243. [CrossRef]

52. Longstaffe, F.J. Stable isotope studies of diagnetic processes. Mineral. Assoc. Can. Saskat. 1987, 13, 187-257.

53. Craig, H. Isotopic variations in meteoric waters. Science 1961, 133, 1702-1703. [CrossRef] [PubMed]

54. Chen, Z.X.; Cheng, J.; Guo, P.W.; Lin, Z.Y.; Zhang, F.Y. Distribution characters and its control factors of stable isotope in precipitation over China. Trans. Atmos. Sci. 2010, 33, 667-679. (In Chinese)

55. Zhu, J.-J.; Chen, H.; Gong, G.-L. Hydrogen and oxygen isotopic compositions of precipitation and its water vapor sources in eastern Qaidam basin. HuanjingKexue/Environ. Sci. 2015, 36, 2748-2790. [CrossRef]

56. Worden, R.H.; Morad, S. Quartz Cementation in Oil Field Sandstones: A Review of the Key Controversies. Quartz Cem. Sandstones 2009, 1-20. [CrossRef]

57. McBride, E.F. Quartz cement in sandstones: A review. Earth Sci. Rev. 1989, 26, 69-112. [CrossRef] 
58. Bjørlykke, K.; Jahren, J. Open or closed geochemical systems during diagenesis in sedimentary basins: Constraints on mass transfer during diagenesis and the prediction of porosity in sandstone and carbonate reservoirs. Am. Assoc. Pet. Geol. Bull. 2012, 96, 2193-2214. [CrossRef]

59. Surdam, R.C.; Crossey, L.J.; Hagen, E.S.; Heasler, H.P. Organic-inorganic and sandstone diagenesis. Am. Assoc. Pet. Geol. Bull. 1989, 73, 1-23.

60. Liu, Y.; Hu, W.; Cao, J.; Wang, X.; Tang, Q.; Wu, H.; Kang, X. Diagenetic constraints on the heterogeneity of tight sandstone reservoirs: A case study on the Upper Triassic Xujiahe Formation in the Sichuan Basin, southwest China. Mar. Pet. Geol. 2018, 92, 650-669. [CrossRef]

61. Lynch, F.L.; Mack, L.E.; Land, L.S. Burial diagenesis of illite/smectite in shales and the origins of authigenic quartz and secondary porosity in sandstones. Geochim. Cosmochim. Acta 1997, 61, 1995-2006. [CrossRef]

62. Tang, L.; Gluyas, J.; Jones, S. Porosity preservation due to grain coating illite/smectite: Evidence from Buchan Formation (Upper Devonian) of the Ardmore Field, UK North Sea. Proc. Geol. Assoc. 2018, 129, 202-214. [CrossRef]

63. Friis, H.; Molenaar, N.; Varming, T. Chlorite meniscus cement-implications for diagenetic mineral growth after oil emplacement. Terra Nov. 2014, 26, 14-21. [CrossRef]

64. Thyberg, B.; Jahren, J.; Winje, T.; Bjørlykke, K.; Faleide, J.I.; Marcussen, Ø. Quartz cementation in Late Cretaceous mudstones, northern North Sea: Changes in rock properties due to dissolution of smectite and precipitation of micro-quartz crystals. Mar. Pet. Geol. 2010, 27, 1752-1764. [CrossRef]

65. Virolle, M.; Brigaud, B.; Bourillot, R.; Féniès, H.; Portier, E.; Duteil, T.; Nouet, J.; Patrier, P.; Beaufort, D. Detrital clay grain coats in estuarine clastic deposits: Origin and spatial distribution within a modern sedimentary system, the Gironde Estuary (south-west France). Sedimentology 2018, 66, 859-894. [CrossRef]

66. Morad, S.; Ketzer, J.M.; DeRos, F. Spatial and temporal distribution of diagenetic alterations in siliciclastic rocks: Implication for mass transfer in sedimentary basins. Sedimentology 2000, 47, 95-120. [CrossRef]

67. Grundtner, M.L.; Gross, D.; Linzer, H.G.; Neuhuber, S.; Sachsenhofer, R.F.; Scheucher, L. The diagenetic history of Oligocene-Miocene sandstones of the Austrian north Alpine foreland basin. Mar. Pet. Geol. 2016, 77, 418-434. [CrossRef]

68. Houseknecht, D.W. Influence of grain size and temperature on intergranular pressure solution, quartz cementation, and porosity in quartzose sandstone. J. Sediment. Petrol. 1984, 54, 348-361. [CrossRef]

69. Ehrenberg, S.N. Assessing the relative importance of compaction processes and cementation to reduction of porosity in sandstones: Discussion; compac-tion and porosity evolution of Pliocene sandstones, Ventura Basin, California: Discussion. Am. Assoc. Pet. Geol. Bull. 1989, 73, 1274-1276.

70. Cao, Z.; Liu, G.; Meng, W.; Wang, P.; Yang, C. Origin of different chlorite occurrences and their effects on tight clastic reservoir porosity. J. Pet. Sci. Eng. 2018, 160, 384-392. [CrossRef]

71. Haile, B.G.; Hellevang, H.; Aagaard, P.; Jahren, J. Experimental nucleation and growth of smectite and chlorite coatings on clean feldspar and quartz grain surfaces. Mar. Pet. Geol. 2015, 68, 664-674. [CrossRef]

72. Line, L.H.; Jahren, J.; Hellevang, H. Mechanical compaction in chlorite-coated sandstone reservoirs-Examples from Middle-Late Triassic channels in the southwestern Barents Sea. Mar. Pet. Geol. 2018, 96, 348-370. [CrossRef]

(C) 2019 by the authors. Licensee MDPI, Basel, Switzerland. This article is an open access article distributed under the terms and conditions of the Creative Commons Attribution (CC BY) license (http://creativecommons.org/licenses/by/4.0/). 